\title{
ŽIVOT OBITELJI S DJECOM U UVJETIMA SIROMAŠTVA IZ PERSPEKTIVE RODITELJA
}

Prethodno priopćenje

Primljeno: kolovoz, 2017.

Prihvaćeno: listopad, 2017.

UDK 364.65-058.34-055.52

DOI 10.3935/ljsr.v24i2.185

\author{
Olja Družić \\ Ljubotina $^{1}$ \\ Sveučilište u Zagrebu \\ Pravni fakultet \\ Studijski centar socijalnog \\ rada
}

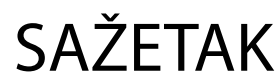

U ovom radu prikazani su rezultati jedne dionice kvalitativnog istraživanja koje se odvijalo kao dio projekta "Indikatori dobrobiti i siromaštva djece u Hrvatskoj u doba krize: Kako prekinuti začarani krug siromaštva djece?", koji je proveo istraživački tim Studijskog centra socijalnog rada Pravnog fakulteta Sveučilišta u Zagrebu uz financijsku potporu Zaklade ADRIS. Cilj prikazanog istraživanja bio je dobiti uvid u perspektivu i mišljenje roditelja djece/mladih o učinku ekonomske krize na dobrobit i kvalitetu života djece i obitelji te specifično o mogućnosti ublažavanja učinaka siromaštva djece. Provedene su dvije fokusne grupe u kojima je sudjelovalo ukupno 14 roditelja srednjoškolaca iz obitelji korisnika prava na zajamčenu minimalnu naknadu. Rezultati su pokazali da je ekonomska kriza nepovoljno djelovala na različite aspekte kvalitete života obitelji i dobrobiti djece. Pokazalo se da je život u materijalnoj oskudici doveo do nemogućnosti zadovoljavanja osnovnih životnih potreba, problema u podmirivanju troškova obrazovanja, narušenih obiteljskih odnosa, razvoja različitih strategija suočavanja sa siromaštvom i dr. S aspekta

Teodor Sabolić

Centar za socijalnu skrb

Varaždin

Marijana Kletečki

Radović ${ }^{3}$

Sveučilište u Zagrebu

Pravni fakultet

Studijski centar socijalnog rada

Ključne riječi:

siromaštvo, djeca, roditelji, dobrobit, resursi lokalnih zajednica.

Izv. prof. dr. sc. Olja Družić Ljubotina, socijalna radnica, e-mail: olja.druzic.ljubotina@pravo.hr

Teo Sabolić, socijalni radnik, e-mail: s.teodor@gmail.com

3 Doc. dr. sc. Marijana Kletečki Radović, socijalna radnica, e-mail: marijana.kletecki.radovic@pravo.hr 
dobrobiti djece, posebno se istaknula dimenzija nezadovoljstva i emocionalne ranjivosti siromašne djece, problemi u odnosima s vršnjacima, nedostupnost informacija, itd. Roditelji zaposlenost vide kao ključni zaštitni čimbenik od siromaštva te naglašavaju važnost podrške i veće razine senzibiliteta stručnjaka koji dolaze u dodir sa siromašnim obiteljima i djecom. Nalazi ovog istraživanja ukazali su na jedan aspekt koji do sada nije bio u fokusu istraživanja siromaštva, a to su razlike u životu i mogućnostima siromašnih obitelji s djecom u bogatijim i siromašnijim zajednicama.

\section{UVOD}

Hrvatska se, kao i brojne zemlje diljem svijeta, suočila s ekonomskom krizom koja je značajno utjecala na povećanje siromaštva i financijske ranjivosti kućanstava, ali i utjecala na promjenu opsega i strukture siromaštva. Pojava »novih siromašnih« relativno je novo obilježje hrvatskog društva, kao posljedica ekonomske krize koja se pojavila 2008. godine (World Bank, 2010.). Prije ekonomske krize tzv. tradicionalno siromaštvo bilo je povezano s dugotrajnom nezaposlenošću i neaktivnošću, pogađajući većinom niskokvalificiranu radnu snagu. Zaposlenje je bilo sigurna brana siromaštvu, što danas više nije. Ipak, ekonomska kriza dovela je do pogoršanja uvjeta života i rada u mnogim zemljama svijeta i uzrokovala još veću nejednakost između određenih skupina stanovništva, a oni koji su već spadali u tzv. ranjive skupine bili su u još većem riziku od siromaštva i socijalne isključenosti (Geinger, Roets i Vandenbroeck, 2017.). Nakon 2010. godine u Europskoj uniji su porasle stope relativnog siromaštva, ali još i više stope siromaštva djece. Rezultati UNICEF-ovog izvješća (2014.) pokazuju da je u 23 od 41 analizirane razvijene zemlje, dječje siromaštvo poraslo od 2008. godine u Irskoj, Hrvatskoj, Latviji, Grčkoj i Islandu, pri čemu su stope siromaštva porasle za više od 50 posto. Šućur (2014.) navodi četiri ključne značajke »novog siromaštva«: financijska neizvjesnost i zaduženost, rastuća nezaposlenost, povećanje broja građana koji žive u apsolutnom ili dubinskom siromaštvu te porast siromaštva djece. U kontekstu porasta siromaštva djece, autor objašnjava ovu činjenicu tezom da su roditelji djece u sve većem riziku gubitka posla ili smanjenih zarada te izloženi većim troškovima obrazovanja. Pritom naglašava da su nepovoljne posljedice gubitka posla osobito prisutne u jednoroditeljskim obiteljima, čiji se broj kontinuirano povećava u Hrvatskoj.

U doba ekonomske krize djeca postaju posebno osjetljiva populacija s obzirom na to da se javlja povećan rizik od siromaštva obitelji i smanjivanje javnih izdataka. Zato djeca koja žive u uvjetima siromaštva posebno ovise o javnim i državnim politikama koje im trebaju omogućiti pristup društvenim resursima (MSPM, 2014.). S druge strane, prema člancima 26. i 27. Konvencije o pravima djeteta, djeca imaju pravo na odgovarajući životni standard i pomoć države u ostvarivanju istog, u slu-

\section{4 članci}


čaju da im njihove obitelji ili skrbnici nisu u mogućnosti osigurati ga. Siromaštvo ostavlja dublje posljedice na djecu nego na odrasle zbog njihove veće ranjivosti koja proizlazi iz dobi i položaja ovisnosti o odraslima. Majke, očevi, obitelji i okruženje u kojem dijete živi imaju neposredan i snažan utjecaj na dobrobit djeteta. U rješavanju problema siromaštva djece, djeca se ne mogu promatrati kao izolirani subjekti, već politike koje su usmjerene na realizaciju dječjih prava i interesa nužno trebaju biti povezane s politikom prema ženama, obitelji i zajednici (Minujin i sur., 2005.). Izvješće Vijeća Europe o pozitivnom roditeljstvu i podršci roditeljima djece izložene riziku siromaštva i socijalnog isključivanja navodi da su za ostvarivanje prava i dužnosti roditelja ključni socijalni uvjeti (Abela i Berlioz, 2007.).

Osim što siromaštvo utječe na djecu, povećani stres uzrokovan siromaštvom obitelji (tzv. ekonomski stres) može negativno utjecati na roditeljsko mentalno zdravlje, roditeljsko ponašanje (stroga disciplina, zanemarivanje), a to može imati negativan učinak na djecu (MSPM, 2014.). Nizak dohodak može djelovati na dobrobit djeteta posredno kroz (Gershoff i sur., 2007.): roditeljski stres (Linver, Brooks-Gunn i Kohen, 2002.; Yeung, Linver i Brooks-Gunn, 2002.), roditeljsko ulaganje novca i vremena u djecu (Guo i Harris, 2000.; Linver Brooks-Gunn i Kohen, 2002.; Yeung, Linver i Brooks-Gunn, 2002.), roditeljsko ponašanje kao što je stroga disciplina ili toplina (Guo i Harris, 2000.; Mistry i sur., 2002.; Yeung, Linver i Brooks-Gunn, 2002.).

Životne poteškoće te odsustvo mogućnosti izbora za mnoge obitelji koje žive u siromaštvu značajno utječu na razvoj djece - njihovo zdravlje, kognitivni razvoj $\mathrm{i}$ opću dobrobit. Djeca u siromašnim obiteljima imaju nižu razinu zdravstvene skrbi, više poteškoća sa završavanjem obrazovanja te stjecanjem višeg stupnja obrazovanja i kvalifikacije za bolje plaćene poslove u budućnosti (Družić Ljubotina i Kletečki Radović, 2016.). Siromaštvo je i dalje jedan od glavnih razloga za institucionalizaciju djece u mnogim zemljama Europske unije, kao i rizik za oduzimanje roditeljske skrbi (Zajedničke europske smjernice za prijelaz s institucionalne skrbi na usluge podrške u zajednici, 2012.). Djeca u siromašnim obiteljima imaju više poteškoća sa završavanjem obrazovanja, stjecanjem višeg stupnja obrazovanja i kvalifikacije za bolje plaćene poslove u budućnosti (MSPM, 2014.).

Iz svega navedenog, jasno je da je siromaštvo višedimenzionalan fenomen te je povezano s različitim aspektima kvalitete života pojedinaca. Specifičnost mjerenja siromaštva djece uključuje i koncept dobrobiti djeteta. Prema Bradshaw, Hoelscher i Richardson (2007.), koncept dječje dobrobiti temelji se na dječjim pravima, koja su navedena u Konvenciji o pravima djeteta te uzima u obzir, uz blagostanje djeteta, i njegove potencijale. Takav pristup, koji polazi od dječjih prava, naglašava važnost dječjih percepcija i aktivnog sudjelovanja djece prilikom razumijevanja i mjerenja njihove dobrobiti. Isti autori nadalje navode da dječja dobrobit nije statičan koncept, što znači da su dječja postignuća posljedica interakcije dostupnih 
resursa i rizičnih čimbenika povezanih s djetetom, obitelji i drugim društvenim institucijama i organizacijama. U konačnici, oni naglašavaju i važnost činjenice da se dječje sposobnosti i potencijali razvijaju u interakciji s okolinom. Pritom polaze od Bronfenbrennerova (1979.) bioekološkog modela ljudskog razvoja koji implicira interakciju unutar i između mikro, mezo, egzo i makrosustava te naglašavaju kako mnogi procesi unutar šire okoline ne pogađaju direktno djecu, no mogu nepovoljno utjecati na njihovo blagostanje posredno preko obitelji. Tu se misli na to da, primjerice, nezaposlenost roditelja utječe na pojavu siromaštva djece $i$ konflikata u obitelji ili ekonomska kriza može utjecati na osiromašenje društva u cjelini (Šućur i sur., 2015.). Dimenzije dječje dobrobiti uključuju: materijalni standard, stanovanje, zdravlje i sigurnost, obrazovanje, obiteljske i vršnjačke odnose, sudjelovanje, ponašanja i rizike te subjektivno blagostanje. Govoreći o konceptu dobrobiti, Raboteg-Šarić (2006.: 128) navodi da ne postoji jedinstvena definicija dobrobiti djeteta. »Dobrobit se može shvatiti kao realizacija djetetovih prava $i$ ispunjenje mogućnosti za svako dijete da bude ono što on ili ona može biti. Dobrobit nije statična, većje rezultat međusobnog djelovanja sredstava ičinitelja rizika koji se odnose na individuu djeteta, osobnu situaciju djetetove obitelji, prijatelja, situacije u školi i šire zajednice u kojoj dijete živi«. Nadalje, ista autorica navodi da je djeci općenito dobro kad je njihovim obiteljima dobro, kad imaju prijatelje i sigurno susjedstvo, kad imaju pristup visokokvalitetnom obrazovanju, zdravstvenoj zaštiti i socijalnim službama i kad im društvo omogućava prostor za razvoj i sudjelovanje. Šućur i sur. (2015.) navode kako je temeljem dosadašnjih istraživanja moguće skicirati zajednički okvir za mjerenje dječje dobrobiti koji sadrži sljedeće dimenzije ili komponente, a koje nalazimo u mnogim istraživanjima. To su: 1. ekonomska (dohodovna) situacija obitelji, 2. stanovanje i lokalna zajednica, 3. dječje zdravlje, 4. dječja sigurnost, 5. obrazovanje, 6. emocionalno blagostanje, 7. rizična ponašanja, 8. kvaliteta odnosa s prijateljima i obitelji, 9. aktivno sudjelovanje u društvu, 10. slobodne aktivnosti te 11. subjektivne percepcije blagostanja. Prvu sveobuhvatnu znanstvenu studiju u Hrvatskoj u kojoj su ispitivani indikatori dječje dobrobiti proveo je UNICEF (Šućur i sur., 2015.), a u fokusu su bile obitelji s djecom predškolske dobi koje koriste pravo na novčanu pomoć iz sustava socijalne skrbi. Cilj ove studije bio je analizirati ne samo pokazatelje dječjeg siromaštva, već i pokazatelje dječje dobrobiti. Preko koncepta dječje dobrobiti naglašava se kompleksnost dječjih života i dječjih odnosa, kao i uloga brojnih čimbenika koji mogu utjecati na životne situacije djece. Pokazalo se da djeca predškolske dobi koja žive u obiteljima pogođenim siromaštvom imaju značajno nižu razinu dobrobiti u odnosu na djecu koja nemaju iskustvo siromaštva. Njihova depriviranost uočena je na svim ispitivanim indikatorima dobrobiti: od materijalne deprivacije, odnosno zadovoljenja osnovnih životnih potreba, stam-

\section{6 članci}


benih uvjeta i karakteristika lokalne zajednice, pristupa aktivnostima i uslugama za djecu do zdravlja, socijalne podrške i dr.

U Nacionalnoj strategiji za prava djece u Republici Hrvatskoj od 2014. do 2020. godine (MSPM, 2014.) posebno se naglašava kako različiti međunarodni dokumenti (Strategija Europa 2020 i Europska platforma protiv siromaštva i socijalne isključenosti) jasno ističu da je smanjenje broja siromašnih i socijalno isključenih osoba u Europskoj uniji jedna od najvažnijih strateških politika i inicijativa. U tom smislu je Europska komisija 2013. godine donijela Preporuku o ulaganju u djecu, uklanjajući nepovoljne okolnosti u kojoj se posebno ističe važnost osiguravanja potpore i podrške kako roditeljima, tako i djeci koja žive u nepovoljnim životnim okolnostima. U Hrvatskoj nemamo dovoljno pokazatelja o tome kako žive djeca i obitelji u uvjetima siromaštva, a osobito ne iz perspektive samih korisnika. Naime, ranije spomenuto istraživanje UNICEF-a u Hrvatskoj (Šućur i sur., 2015.) je prvo takvo koje je uključivalo korisničku perspektivu, jer su sudionici bili roditelji iz siromašnih obitelji s predškolskom djecom i svjedočili o tome kako je podizati djecu u uvjetima siromaštva. Istraživanje, čiji će dio biti prikazan u ovom radu, polazi od prva dva prioriteta propisanih Nacionalnom strategijom za prava djece u Republici Hrvatskoj od 2014. do 2020. godine (MSPM, 2014.), a koja se tiču područja zaštite prava djece koja žive u uvjetima siromaštva. To su: 1. zaštititi djecu od rizika i posljedica siromaštva i 2. unaprijediti položaj djece koja žive u uvjetima siromaštva u okviru različitih sustava socijalnih politika. Kako bi bilo moguće ispuniti ove prioritete, nužno je imati pokazatelje na temelju kojih se mogu donositi ciljane mjere zaštite djece od siromaštva i unapređenje njihovog položaja. Provođenja istraživanja u kontekstu siromaštva djece zasigurno predstavljaju značajan doprinos u ostvarenju prioritetnih nacionalnih ciljeva zaštite djece od rizika i posljedica siromaštva.

U okviru šireg istraživačkog projekta provedeno je sveobuhvatno istraživanje koje se temeljilo na kvalitativnoj metodi prikupljanja i analize podataka ${ }^{4}$. Uzorak sudionika bio je podijeljen u četiri podskupine te je obuhvaćao: djecu i mlade koji žive u uvjetima siromaštva, njihove roditelje, stručnjake koji rade $s$ djecom i obiteljima koji žive u siromaštvu te ključne društvene dionike i zagovaratelje prava djece (donositelji politika). Ovakav pristup formiranja uzorka sudionika omogućio je sagledavanje i produbljivanje razumijevanja fenomena siromaštva djece iz različitih perspektiva. U nastavku rada bit će prikazan segment istraživanja u kojem je u fokusu bila perspektiva roditelja koji žive u uvjetima siromaštva.

4 Rad je nastao kao dio projekta »Indikatori dobrobiti i siromaštva djece u Hrvatskoj u doba krize: Kako prekinuti začarani krug siromaštva djece?«. Projekt je proveo istraživački tim Studijskog centra socijalnog rada Pravnog fakulteta Sveučilišta u Zagrebu uz financijsku potporu Zaklade ADRIS. 


\section{CILJ ISTRAŽIVANJA}

Cilj ovog rada je dobiti uvid u perspektivu i mišljenje roditelja o učinku ekonomske krize na dobrobit i kvalitetu života djece i obitelji te specifično o mogućnosti ublažavanja učinaka siromaštva djece. Mišljenje roditelja koji žive u uvjetima siromaštva ima poseban značaj i relevantnost za razumijevanje problema života siromašnih obitelji i djece s obzirom na iskustvenu perspektivu sudionika.

\section{ISTRAŽIVAČKA PITANJA}

Polazeći od cilja, istraživačka pitanja su:

1. Što roditelji iz siromašnih obitelji misle o učinku siromaštva i ekonomske krize na život djece i njihovih obitelji?

2. Kako roditelji iz siromašnih obitelji opisuju dobrobit djece i mladih koje žive u siromaštvu?

3. Kako roditelji iz siromašnih obitelji doživljavaju socijalnu podršku?

4. Koje su mogućnosti ublažavanja učinaka siromaštva djece i obitelji iz perspektive roditelja iz siromašnih obitelji?

\section{METODA}

Istraživački nacrt temelji se na kvalitativnoj metodi prikupljanja i analize podataka. U istraživanju su sudjelovali roditelji srednjoškolaca koji žive u uvjetima siromaštva. Podaci su prikupljeni metodom fokusnih grupa.

\section{Sudionici istraživanja}

U istraživanju je sudjelovalo 14 roditelja iz obitelji korisnika zajamčene minimalne naknade. Ovo novčano pravo unutar sustava socijalne skrbi ostvaruju obitelji i pojedinci koji nemaju sredstava za podmirenje osnovnih životnih potreba (Zakon o socijalnoj skrbi, 2013., 2014., 2015., 2016., 2017.). Radi se o korisnicima koji se nalaze u dohodovno najnepovoljnijoj situaciji. Roditelji su bili okupljeni u dvije fokusne grupe: (1) roditelji iz siromašne zajednice (7 sudionika) i (2) roditelji iz bogate zajednice (7 sudionika). U istraživanje su bili uključeni roditelji iz bogatije i siromašnije zajednice, koje se razlikuju prema visini stope rizika od siromaštva sukladno nalazima o depriviranosti zajednica te raspodjeli rizika od siromaštva i socijalne isključenosti u $\mathrm{RH}$. Nacionalna stopa rizika od siromaštva u vrijeme istraživanja iznosila je 19,4\%, a uključene su zajednice s niskom $(9,8 \%)$ i višom stopom rizika od siromaštva $(27,4 \%)$

\section{8 članci}


(DZS, 2015., 2016.). Ovakav pristup omogućio je dobivanje uvida na učinke siromaštva djece i obitelji u kontekstu okolinskih obilježja zajednice, koje posredno mogu ublažiti ili otežati život djeteta i obitelji u siromaštvu. Od 14 roditelja u fokusnim grupama je bilo ukupno devet majki i pet očeva. U siromašnijoj zajednici su svi roditelji imali troje i više djece, dok su u bogatijoj imali jedno do troje djece. Sudionici su ujedno i roditelji srednjoškolaca koji su sudjelovali u sklopu šireg istraživanja.

\section{Metoda prikupljanja podataka}

Istraživanje je provedeno metodom fokusne grupe. Provedene su dvije fokusne grupe u kojima je sudjelovalo 14 roditelja srednjoškolaca koji žive u uvjetima siromaštva. U siromašnijoj i u bogatijoj zajednici provedena je po jedna fokusna grupa s po sedmero roditelja u svakoj. Na fokusnim grupama sudjelovali su voditelj i suvoditelj koji je vodio bilješke razgovora. Razgovor u fokusnim grupama trajao je oko 90 minuta. Razgovore sa sudionicima proveli su iskusni stručnjaci (ujedno i autori ovog istraživanja), koji imaju višegodišnje iskustvo u vođenju fokusnih grupa. Od roditelja je zatražena suglasnost za snimanje razgovora kao i njegov prijepis. Zajamčena je anonimizacija podataka budući da se nisu zadržavali nikakvi identifikacijski podaci, a prilikom prikaza rezultata istraživanja, odnosno odgovora sudionika koristili su se pseudonimi. Uz sačuvane snimke i transkripte fokusnih grupa također se nisu vezali nikakvi identifikacijski podaci. Nakon transkribiranja audio verzije su uništene. Primjenom ovih postupaka, sudionicima se ujedno osigurala povjerljivost njihovih iskaza.

Fokusne grupe vođene su prema unaprijed pripremljenom predlošku za strukturirani razgovor, koji je obuhvaćao četiri tematske cjeline. Za svaku tematsku cjelinu navedeni su primjeri pitanja:

1. Ekonomska kriza:

- Kako se ekonomska kriza odrazila na život vaše obitelji i djece? Tko je u vašoj obitelji najviše uskraćen u svojim željama i potrebama zbog ekonomske krize?

- Kako se to odrazilo na vas? Kako na vašu djecu? S kojim poteškoćama se kao roditelj najviše suočavate zbog ekonomskih teškoća? Koja rješenja nalazite za nošenje s teškoćama ekonomske krize?

- Jeste li primijetili da su vaša djeca zabrinuta ili uznemirena zbog lošijeg materijalnog stanja obitelji? Ako da, na koji način to pokazuju?

- Što biste rekli da vaša obitelj i ostale obitelji lošijeg materijalnog statusa nemaju, a one boljeg materijalnog statusa imaju? U čemu se djeca iz siromašnih obitelji uskraćena? Čega se sve odričete zbog ekonomskih teškoća? 
- Kako se lošije materijalne prilike u vašoj obitelji odražavaju na vaše zadovoljstvo životom općenito?

2. Dobrobit djece i mladih u kontekstu siromaštva:

- Na koji način se ekonomska kriza u društvu nepovoljno odrazila u životu vašeg djeteta na neke osnovne životne potrebe, školovanje, prijateljstvo i odnose s vršnjacima, način provođenja slobodnog vremena, uključenost u aktivnosti svoje zajednice, vaše raspoloženje i osjećaje, vaše zdravlje i zdravlje članova vaše obitelji, odnose u obitelji?

- Imaju li vaša djeca pristup informacijama koje su im potrebne jednako kao i ostali vršnjaci? Imaju li pristup internetu i drugim izvorima informacija?

- Smatrate li da mladi koji su lošijeg materijalnog statusa mogu slobodno izraziti svoja mišljenja i uvjerenja jednako kao i oni mladi ljudi koji žive u boljim ili jako dobrim materijalnim okolnostima?

- Je li mladim ljudima koji žive u lošijim materijalnim uvjetima teže doći do informacija koje su im potrebne, za npr. školu ili za neke druge aktivnosti?

3. Socijalna podrška djeci/mladima i roditeljima koji žive u uvjetima siromaštva:

- Tko pomaže vama i vašem djetetu? Kako doživljavate podršku iz okoline?

4. Mogućnosti ublažavanja učinaka siromaštva djece iz perspektive roditelja:

- Kako društvo/država najbolje može pomoći mladima, djeci i obiteljima koja žive u uvjetima siromaštva i ekonomskih teškoća? Koji su vaši prijedlozi za poboljšanje života djece i obitelji koje žive u siromaštvu?

- Što bi stručnjaci (nastavnici, socijalni radnici, liječnici, netko drugi) trebali znati o siromaštvu i ekonomskim teškoćama djece i mladih i obitelji?

\section{Postupak istraživanja}

U izboru sudionika sudjelovali su djelatnici centara za socijalnu skrb koji su iz svoje dokumentacije o obiteljima korisnicima zajamčene minimalne naknade izdvojili roditelje srednjoškolaca trogodišnjih i četverogodišnjih obrazovnih programa. Stručnjaci centara za socijalnu skrb telefonski su kontaktirali roditelje te po unaprijed pripremljenim predlošcima tražili suglasnost za sudjelovanje. Ukoliko su roditelji dali pristanak da sudjeluju u istraživanju, ponovno ih je kontaktirao istraživač te dogovarao susret u fokusnoj grupi. Za svakog roditelja koji je sudjelovao u istraživanju predviđen je prigodan dar zahvale o čemu su bili prethodno obaviješteni. $U$ telefonskom razgovoru, kao i na početku fokusne grupe, sudionici su bili upoznati sa svrhom i ciljevima istraživanja. Etičnost istraživačkog postupka u provedbi ovog dijela istraživanja bila je osigurana kroz usmeni informirani pristanak

\section{0 članci}


budući da su svi sudionici prije provedbe fokusnih grupa bili detaljno informirani o svrsi i cilju istraživanja kao i o njegovim provoditeljima te se također tražio i njihov pismeni pristanak za sudjelovanje u istraživanju. Svi sudionici bili su informirani o dobrovoljnosti njihova sudjelovanja u istraživanju kao i o mogućnosti odustajanja u bilo kojem trenutku provedbe. Etičko povjerenstvo Pravnog fakulteta Sveučilišta u Zagrebu odobrilo je nacrt ovog istraživanja. Istraživanje je provedeno u razdoblju od svibnja do srpnja 2015. godine u prostorima centara za socijalnu skrb u kojima roditelji ostvaruju pravo na socijalnu naknadu.

\section{Analiza podataka}

Podaci su obrađeni postupkom analize okvira (engl. framework analysis). Postupak analize okvira razvio se specifično za primijenjena istraživanja, a u kontekstu istraživanja javnih (socijalnih, zdravstvenih i sl.) politika s ciljem dobivanja specifičnih informacija koje će omogućiti određene uvide i preporuke u kraćem vremenskom razdoblju (Ritchie i Spencer, 1994.). Ono što karakterizira analizu okvira su unaprijed definirane teme na koje istraživači žele dobiti odgovore. Dakle, radi se o kvalitativnim istraživanjima u kojima postoje unaprijed definirana istraživačka pitanja na koja treba dati odgovor u kraćem vremenskom roku i kad postoji uzorak koji je namjerno odabran (pod vidom definiranih tema, odnosno istraživačkih pitanja) (Lacey i Luff, 2009.). Neki autori napominju kako je opravdano da je u ovom tipu istraživanja uzorak namjerno odabran s obzirom na istraživačka piranja na koja je potrebno dati odgovor u kratkom vremenskom roku (Srivastava i Thomson, 2009.). To omogućava preporuke i uvide koji mogu poslužiti donositeljima odluka i akterima socijalne politike, u ovom slučaju, na području siromaštva djece. Proces obrade podataka obuhvaća pet međusobno povezanih koraka (Ritchie i Spencer, 1994.): upoznavanje građe, postavljanje tematskog okvira, kodiranje, odnosno indeksiranje izjava sudionika, unošenje u tablice radi bolje preglednosti rezultata, povezivanje i interpretaciju rezultata. Podatke su neovisno analizirala dva istraživača koji su u posljednjem koraku usporedili analize i dobivene rezultate te uskladili istraživačke nalaze kako bi se pokušala umanjiti njihova pristranost. Izjave sudionika analizirane su tako da su jedinice analize kodirane na temelju sličnosti sadržaja i tako su definirani pojmovi, koji su zatim apstrahirani u kategorije. Dobiveni nalazi, odnosno pojedini pojmovi u prikazu rezultata ilustrirani su izjavama sudionika, koje su zbog povjerljivosti označeni šiframa (RSZ - roditelji iz siromašne zajednice; RBZ - roditelji iz bogate zajednice). Zbog bolje preglednosti pojmovi i kategorije koji se odnose na iste teme organizirani su u tabličnim prikazima. 


\section{REZULTATI}

Rezultati su prikazani u okviru četiri tematska područja definirana istraživačkim okvirom: 1. Odraz ekonomske krize na život obitelji; 2 . Dobrobit djeteta u kontekstu odrastanja u uvjetima siromaštva; 3 . Socijalna podrška obiteljima koje žive u uvjetima siromaštva; 4. Mogućnosti ublažavanja učinaka siromaštva djece iz perspektive roditelja. Kroz određene tematske cjeline specifično su istaknuti rezultati koji ukazuju na ono što je:

- zajedničko svim roditeljima koji žive u uvjetima siromaštva

- specifične razlike između roditelja koji žive u siromašnijoj i bogatijoj zajednici.

\section{Odraz ekonomske krize na život obitelji}

Prvo definirano tematsko područje odnosilo se na odraz ekonomske krize na život obitelji. U Tablici 1 prikazani su učinci ekonomske krize i siromaštva na život mladih i njihovih obitelji koje izdvajaju svi roditelji koji žive u uvjetima siromaštva. Naime, pokazalo se da nema specifičnih razlika glede ovog tematskog područja s obzirom na to žive li roditelji u siromašnoj ili bogatoj zajednici.

Rezultati pokazuju da se ekonomska kriza odrazila na nekoliko aspekata života obitelji. Jedan od njih koji roditelji ističu je »nemogućnost zadovoljavanja osnovnih životnih potreba i pad životnog standarda«. Nemogućnost zadovoljavanja osnovnih životnih potreba odnosi se na »oskudijevanje u prehrani« članova obitelji: »Ja mislim hrana... teško se plaća." (RBZ5); »A ovo što dobijem tih 1100 kuna, to kaj mi ostane za klopu, kaj kupim najnužnije. Znači, brašno, šećer, prašak i tako ono kaj treba.« (RBZ6); "nepriuštivost nove odjeće i obuće«: »Skupe tenisice, odjeća djecije najgora... «(RSZ2);»Ja mislim.. odjeća... teško se plaća." (RBZ5), „poteškoće u podmirivanju režijskih troškova«: "Evo, sad mi je prošli mjesec došla opomena za struju, sa 600 kuna na 2100 kuna, da ce me isključit'« (RSZ6); »Bili smo bez struje mjesec i pol jer oni nisu dali ni obavijest ni ništa, oni su samo došli, izvadili osigurače i to je to.« (RBZ7). Roditelji navode da je bio "lakši život prije ekonomske krize«: »Ja sam znao ići stubišta čistit'. 20 godina sam živio s pokojnom mamom. Mi smo čistili osam stubišta, ali to je 3000 kuna lijepih mjesečno bilo, plus njezina plaća i moja plaća. To se dalo pokrivati, lijepo se moglo živjet'. Ali, danas toga više nema." (RBZ6). Pad životnog standarda očituje se i u »nemogućnosti odlaska na ljetovanje«: »/ zove me brat na more, ne da me ne zove, al meni do tamo treba i za gorivo i ne mogu ja samo tam doć na plažu. (RSZ7), ali i u »teškoćama održavanja dotrajalih automobila«: »A što se tiče tih auta, pretežno mi vozimo auto po 80 i neko godište... 2400 kuna je registracija, al doslovce cijele godine moram odvajat, pogotovo ovaj zadnji mjesec, sve moraš dat i još namirit..." (RSZ7).

\section{2 članci}


Tablica 1. Odraz ekonomske krize na život obitelji - zajedničko svim roditeljima koji žive u uvjetima siromaštva

Tema: Odraz ekonomske krize na život obitelji

\begin{tabular}{|c|c|}
\hline Kategorije & Pojmovi \\
\hline \multirow{6}{*}{$\begin{array}{l}\text { Nemogućnost zadovoljavanja } \\
\text { osnovnih životnih potreba i } \\
\text { pad životnog standarda }\end{array}$} & Oskudijevanje u prehrani \\
\hline & Nepriuštivost nove odjeće i obuće \\
\hline & Poteškoće u podmirivanju režijskih troškova \\
\hline & Lakši život prije ekonomske krize \\
\hline & Nemogućnost odlaska na ljetovanje \\
\hline & Teškoće održavanja dotrajalih automobila \\
\hline \multirow{5}{*}{ Problemi vezani uz sferu rada } & Teškoće zapošljavanja mladih i odlazak u inozemstvo \\
\hline & Nezaposlenost kao posljedica dobi \\
\hline & Nužnost veza i poznanstava za pronalazak posla \\
\hline & Povremeni poslovi kao izvor nestabilnosti \\
\hline & Stalan posao kao izvor sigurnosti \\
\hline \multirow{2}{*}{$\begin{array}{l}\text { Nemogućnost podmirenja } \\
\text { specifičnih potreba djece }\end{array}$} & Nemogućnost podmirenja troškova obrazovanja \\
\hline & Nemogućnost podmirenja osobnih potreba djeteta \\
\hline \multirow{2}{*}{ Narušeni obiteljski odnosi } & Problemi u odnosu roditelj-dijete \\
\hline & Nezadovoljstvo u obitelji \\
\hline \multirow{2}{*}{$\begin{array}{l}\text { Problemi povezani sa } \\
\text { zdravljem }\end{array}$} & Narušeno zdravlje zbog života u siromaštvu \\
\hline & Problem pronalaska posla zbog narušenog zdravlja \\
\hline \multirow{5}{*}{$\begin{array}{l}\text { Strategije nošenja } \\
\text { sa siromaštvom }\end{array}$} & Uključivanje djece u rad i uzdržavanje obitelji \\
\hline & Povremeni poslovi kao dodatni izvori zarade roditelja \\
\hline & Štednja na osnovnim životnim troškovima \\
\hline & Odricanje roditelja \\
\hline & Posuđivanje novca \\
\hline
\end{tabular}

Roditelji, kao posljedicu ekonomske krize, ističu »probleme vezane uz sferu rada«. To se odnosi na »teškoće zapošljavanja mladih«: »Ona sad godinu dana sjedi doma, di god se javi, nema radnog iskustva. Nigdje ih ne žele primiti kao praktikante... nemaju posla mladi. Moja kćer je prošle godine završila trgovačku i javlja se stalno, nema. Znači, 19 godina, nemaju posla." (RBZ4) i »odlazak u inozemstvo«: »l sad bi ga susjed van vodio radit, u Austriju, al ne može sa 17 godina, kaže ne biram šta ću radit, samo da odem radit." (RSZ7); "Svi, čim završe školu idu van." (RSZ3). Roditelji ističu svoju »nezaposlenost kao posljedicu dobi«: »Ne znam, 52 godine, ko će me zaposlit." (RSZ6); "Ljudi koji su zaista u teškoj socijalnoj situaciji, koji su već u pozamašnim godinama, ne možemo se zaposliti jer nas poslodavci više jednostavno ne žele." (RBZ1), a povezuju je i s »nužnosti veza i poznanstava za pronalazak posla«: »Ja sam jedina na ovome području imala školu završenu, kuharsku. Al, primljena je žena koja nije imala škole, išla naknadno polagat samo 
da radi. Pa čemu sam išla u školu, čemu?... al se znalo kog će primit." (RSZ7). „Povremeni posao kao izvor nestabilnosti« također je apostrofiran od strane roditelja: »...nigdje mi nikad niko nije ponudio posao, osim sezone. A kao majka troje djece ne mogu otić na sezonu. Raskopat svoj brak i otići tri mjeseca na sezonu." (RSZ2). Naposljetku, roditelji ističu važnost »stalnog posla kao izvora sigurnostik:»Važnoje imati sigurno plaćen posao. Standard života im je bolji.« (RBZ6); »Ja mislim da je jako teško o tome pričat'jer zaposleni imaju mogućnost kredita. Na kredit mogu kupiti bicikl, motor, vikendicu, auto, znači, to im je otvoreno. Oni imaju sigurnost." (RBZ2); »Imaju više novaca, imaju više mogućnosti za kupit' ono što naša djeca žele, a mi to ne možemo, nemamo mogućnost." (RBZ5).

Kao posljedicu ekonomske krize roditelji ističu »nemogućnost podmirenja specifičnih potreba djece«. To se prije svega odnosi na »nemogućnost podmirenja troškova obrazovanja«: "Moj bi i sad trebao na maturalac, ali ne može." (RBZ7) te "nemogućnost podmirenja osobnih potreba djeteta«: »Ako im dam jedanput u mjesec dana 50 kuna da raspodijele za neki sladoled... Nemam." (RBZ3); "Njegovi u razredu imaju onaj iPhone u vrijednosti 8-9 tisuća kuna, a on nema ni džeparac." (RBZ7); »Pa eto, neka traže za bon za mobitel, ja im moram priuštit, a ne mogu... Mislim, ne mogu priuštit 30 kuna za bon." (RSZ4).

Roditelji naglašavaju i »narušene obiteljske odnose«. Pritom ističu različite "probleme u odnosu roditelj-dijete«: »Moja djeca nas ne razumiju, roditelje osuđuju stalno. Govore da smo mi krivi." (RSZ4); "Znate što kažu? 'A što si me rodila, kad mi ne možeš priuštit'? (RBZ4); »Moj sin zna reći: 'Mama, nisi se dovoljno potrudila da nađeš posao." (RBZ7); »l sad su bili ogorčeni na nas zašto smo mi isključili internet. Nemamo mobitela, nemamo biciklo, dobro, nemamo izać, kud još si nam i sad internet isključila." (RSZ7); »Ne voliš me, ne značim ti ništa. Neke riječi znaju toliko pogodit', da zna zabolit' to. Zna predbacit': 'Pa nećeš ić' negdje posudit'?' 'Ja da mogu posudit', onda bih posudio, ali to treba i vratit'. Kak' je krenulo, nikad se ne zna što tebe bude u životu snašlo.' - rekoh. Samo što oni ne shvaćaju bit toga, jer to je njima igra ruskog ruleta - sad imaš, sad nemaš." (RBZ6). Roditelji ističu i općenito prisutnost osjećaja »nezadovoljstva u obitelji«: »Negativna situacija i negativna je slika.«(RKH6); »Napetost, nervoza.« (RSZ4).

Poznato je da je siromaštvo povezano s lošijim zdravljem. To se pokazalo i u ovim rezultatima gdje roditelji ističu »probleme povezane sa zdravljem«. S jedne strane, navode kako im je »narušeno zdravlje zbog života u siromaštvu«: "Svi smo mi zbog nekih problema malo zdravlje i izgubili. Svi to nama kažu zdravlje je najpreče, pa i novac je najpreči, kad nemaš novaca, mi smo svi bolesni, doslovce ne možeš ni doktoru otići, ni rodit se ni umrijet bez novca." (RSZ7).

$S$ druge strane, problemi vezani sa zdravljem se očituju i u »problemu pronalaska posla zbog narušenog zdravlja«: »Jer mnogi mi imamo djecu izdravstvena stanja, ja sam operirao kičmu, na primjer. Ne mogu sad radit' bilo kakav posao, a naizgled sve pet." (RBZ2); »... ko će me zaposlit.. Imam tri kronične bolesti, ranjavan, ne znam." (RSZ6); »Radila sam.. bila sam na bolovanju, onda mi je dao otkaz.. (RSZ4).

\section{4 članci}


Roditelji navode »strategije nošenja sa siromaštvom« koje vide kao direktnu posljedicu dodatno otežanih uvjeta života u doba ekonomske krize. Jedna od strategija je »uključivanje djece u rad i uzdržavanje obitelji«: »Onda oni idu, sidne na biciklo i odu pitat stare ljude kome treba cijepat drva, kome treba nešto da bi si oni zaradili." (RSZ7), kao $i$ »povremeni poslovi i rad na crno«: »Cijepanje drva, rezanje drva. A za tih 100 kuna se treba pošteno namučit'.. (RBZ6); "Jako malo možemo mi prosperitat' u poslu. I ja idem krečit'.." (RBZ2), »Radi na crno, snalazi se." (RBZ2); " „a ošišam i susjeda malo pa ostavi 10-20 kuna, pa netko donese 10 deka kave, nekome mije uopće žao uzet' pa mu ošišam dijete..." (RBZ7). Kako bi lakše prebrodili tešku materijalnu situaciju roditelji pribjegavaju »štednji na osnovnim životnim troškovima«: »Način uštede za mene - ja u second-hand shopovima kupujem odjeću za sebe." (RBZ2); "Sreća moja što imam dečke, jer ovaj stariji preraste, onda ovaj mlađi nosi.« (RBZ7); »Znači, što je na akciji, to se danas kupi i stavi se u škrinju." (RBZ2), "Doslovce, živi se i hrani se od akcija. Ideš po trgovinama i gledaš ako je što na akciji pojest ćeš, ako i nije, čekat ćeš tu akciju pa ćeš..." (RSZ7); »Ja uvijek kupim čajnu za gablec u školi, nešto za djecu, za sendvič. Kaže kćer: 'Mama, nezgodno mi je, uvijek iz torbe da vadim, daj mi džeparac.'« (RBZ3); "Mi ne idemo u pučku kuhinju. Imamo doma par kokica i vrt, s tim se zabavljam, koliko mogu ušparat'." (RGZ7); „Prije 4 godine sam kupila aparat za šišanje da ne moram davat' za frizera. M. je moj tad bio 5 godina i meni je to bilo prestrašno - 60 kuna za šišanje." (RSZ6). »Odricanje roditelja« da bi mogli zadovoljiti potrebe svoje djece, također je jedna od strategija nošenja sa siromaštvom: »Moja kćer, ova što ide u drugi srednje... Znam kako sam odvajala novce za nju, samo da ide. Plakala je samo da ide. Evo, ovaj mjesec neću platit' režije, tebi ću platit' izlet." (RBZ3); "Nisam bio u kafiću već nekoliko godina." (RBZ1); "Ja se nit' ne farbam." (RBZ7); »Na uštrb svega, ne puši se, ne pije se, pojede se koliko se ima, razvuče se, samo da djeca imaju..." (RSZ6). Naposljetku, roditelji nerijetko »posuđuju novac od svojih prijatelja i obitelji kako bi uspjeli podmiriti osnovne životne potrebe: »... opet odi posudit', vraćaj i opet sam nigdje. Opet se vrtim stalno u krug k'o miš u kolutu. (RBZ6); "Ovako ako treba posudit novac za lijek kad se razboli netko, ja ili muž, za put do bolnice, to možemo posudit..." (RSZ4).

Kao što je na početku navedeno, s obzirom na temu kako se ekonomska kriza odrazila na život obitelji, analizom podataka nisu ustanovljene specifičnosti u kontekstu razlika između siromašnije i bogatije zajednice.

\section{Dobrobit djeteta u kontekstu odrastanja u uvjetima siromaštva}

U cilju boljeg razumijevanja kvalitete života djece i mladih koji odrastaju u obiteljima u uvjetima siromaštva, u zajednicama koje imaju različite resurse i kapa- 
citete na raspolaganju, u fokusnim grupama s roditeljima razgovaralo se o različitim aspektima dobrobiti djeteta koji se odnose na osnovne životne uvjete, zdravlje, odnose s obitelji, odnose s vršnjacima, obrazovanje, slobodno vrijeme, sudjelovanje u zajednici, pristup informacijama, osjećaje te slobodu izražavanja vlastitog mišljenja i uvjerenja. U nastavku ćemo prikazati pojedine indikatore dobrobiti djece koje roditelji posebno ističu u kontekstu života u uvjetima siromaštva (Tablica 2.).

Tablica 2. Dobrobit djeteta u kontekstu odrastanja u siromaštvu iz perspektive roditelja - zajedničko svim roditeljima

\begin{tabular}{|c|c|}
\hline Kategorija & Pojam \\
\hline \multirow{2}{*}{$\begin{array}{l}\text { Nezadovoljstvo i } \\
\text { emocionalna ranjivost djece }\end{array}$} & $\begin{array}{l}\text { Nezadovoljstvo djece teškom materijalnom situacijom } \\
\text { obitelji }\end{array}$ \\
\hline & Osjećaji srama i straha \\
\hline \multirow{3}{*}{$\begin{array}{l}\text { Različita iskustva u odnosu s } \\
\text { vršnjacima }\end{array}$} & Kvalitetan odnos s vršnjacima \\
\hline & Isključivanje djece iz vršnjačkih skupina zbog siromaštva \\
\hline & $\begin{array}{l}\text { Emocionalno zlostavljanje i stigmatiziranost siromašne } \\
\text { djece }\end{array}$ \\
\hline \multirow{3}{*}{ Podržavajući odnosi u obitelji } & Podržavajući odnos između roditelja i djece \\
\hline & Povjerenje u roditelje \\
\hline & Prihvaćanje teške materijalne situacije obitelji \\
\hline \multirow{4}{*}{$\begin{array}{l}\text { Problemi u pristupu } \\
\text { obrazovanju i informacijama }\end{array}$} & Teškoće podmirivanja troškova obrazovanja \\
\hline & Neusklađenost obrazovnog sustava s tržištem rada \\
\hline & Nemogućnost korištenja računala i interneta \\
\hline & Nedovoljna informiranost o pravima \\
\hline \multirow{2}{*}{$\begin{array}{l}\text { Pozitivan odnos djece prema } \\
\text { obrazovanju }\end{array}$} & Dobra obrazovna postignuća djece \\
\hline & Odgovornost prema školskim obvezama \\
\hline
\end{tabular}

Osjećaj »nezadovoljstva i emocionalnu ranjivost djece« roditelji posebno ističu u kontekstu osjećaja s kojima se njihova djeca nose, a koji su povezani sa životom u siromaštvu. Roditelji ističu vrlo prisutno »nezadovoljstvo djece teškom materijalnom situacijom obiteljik: »Jer sva naša djeca su nezadovoljna, kao što ste čuli, statusom da je netko socijalni slučaj ili da prima socijalnu pomoć." (RBZ2); »Ma teško. Ovaj, sin je isto nezadovoljan, završio je 3. u srednjoj, bez kompjutora skroz, nemamo ni kompjutor kod kuće, ima stari mobitel.» (RSZ5). Kod djece su prisutni »osjećaji srama i straha« od osude vršnjaka zbog siromaštva: »Njih je doslovce istid reć da nemaju internet.« (RSZ7); »Prošle godine sam ja morala ić sredit za kartu, za autobusnu kartu ima besplatno, nije htio reć, kadje razrednica pitala.." (RSZ7); »On kaže: 'Neću, radit ću rađe na crno, nego se prijavit na burzu i čekat posao, pa da dobivamo socijalnu pomoć.', da ne čuju to njegovi

\section{6 članci}


prijatelji.» (RBZ2); »Reagirao je da ako bismo išli u pučku kuhinju, da više neće ići ni u školu, jer da će netko vidjeti od roditelja i da će djeca saznati." (RBZ1).

S obzirom na indikator dobrobiti djece koji je vezan za odnose s vršnjacima, roditelji navode »različita iskustva u odnosu s vršnjacima«. S jedne strane, ističu kako njihova djeca imaju »kvalitetne odnose s vršnjacima«: »Moje dvije kćeri ne taje uvjete života. Cure koje idu u srednju školu sa starijom kćeri ništa ne gledaju manje na moju kćer zato što one imaju više, a moja kćer, na primjer, nema to, to i to. Ne ocjenjuju je da manje vrijedi nego one. Druže se jednako i neki put kad nema moja kćer, na primjer, 50 kuna, one uvijek uskoče. Tretiraju je jednako. Stvarno mi se to sviđa. Ja sam sve te cure upoznao, fenomenalna ekipa."(RBZ6). S druge strane, roditelji češće ističu probleme koje njihova djeca imaju s vršnjacima zbog teške materijalne situacije. Jedan od problema s kojima se djeca suočavaju je »isključivanje djece iz vršnjačkih skupina zbog siromaštva«: "Dečki moji su najviše zakinuti u odnosima s vršnjacima... niti steći prijatelje, ne žele s vama uopće razgovarat." (RBZ7), koje je vrlo usko povezano s vrlo prisutnim »emocionalnim zlostavljanjem i stigmatiziranosti siromašne djece«: »...nije mogao počastiti za svoj rođendan... da ne velim s kakvim je uvredama došao kući." (RBZ7); »Mada je što kaže u srednjoj školi, ako nemaju ono što imaju drugi, onda djeca se rugaju." (RSZ1); "Sad su ove godine išli u neko selo na jednodnevni izlet gledat' kokoši ipatke, onda su mu rekli: 'Pa ti to imaš doma, ti ne trebašni ić.'. On je poludio: 'Mama, to nije za ruganje, mama, to je za hranu!' Ja to sve znam, ali ne možeš neke stvari objasniti." (RBZ7); »A kad to klinci sa strane skuže, e, onda su odbačeni jako, da ne velim koji su to pogrdni izrazi, kak'se njih gleda, kak'se njih tretira." (RBZ6).

Odnosi u obitelji su važan indikator dječje dobrobiti pri čemu roditelji siromašne djece ističu prisutnost »podržavajućih odnosa u obiteljik. To se odnosi prije svega na "podržavajući odnos između roditelja i djece«: »Kad je njima teško, ja s njima sjednem pa ćemo nać' neko rješenje, negdje mora bit' nešto." (RBZ6); »Pa...ja sve činim da oni to ne osjete, da ja ne vidim da su zabrinuti, ja bi volio da nikad ne vidim da su zabrinuti, tako da, al djeca znaju i sakrit malo." (RSZ6); »Meni je sin jednom prigodom rekao: 'Mama, ja jedva čekam da doživim da negdje zaradim prvu plaću.' 'Pa šta bi ti s tom prvom plaćom?' 'Pa prvih 100 eura dao bi tebi i odveo te u trgovinu i ti reci, dušo, šta želiš da ti kupim.'" (RSZ7). Kao aspekt podržavajućih odnosa unutar obitelji istaknuto je »povjerenje u roditelje«: »... meni dijete kaže kako mu je, da neka profesorica lijepo postupi, meni to dijete kaže, ova mi je valjala profesorica, tako mi je izašla u susret, nisam mogla taj dan nešto učit, nešto me bolilo ovo ono. To je dosta.«( RSZ6)). Podržavajući odnosi unutar obitelji povezani su i s "prihvaćanjem teške materijalne situacije obiteljik, što znači da djeca iskazuju razumijevanje i svijest za probleme s kojim se obitelj suočava: »...ona će tražit, e mama meni treba tenisice, treba mi hlače, treba mi ovo, i kad vidi da nemamo, ona to i prešuti neki put. A nije sad ko ona druga djeca, e mama ja sam vidla kod one tenisice neke, neće tražit, znači ide po nama, kako 
mi imamo primanja, se prilagodi." (RSZ3); »Ja sam svoju djecu odgojio, otkad sam upao u to, da smo mi socijalni slučaj i da hvala državi koja nam pomaže toliko koliko pomaže." (RBZ2); »To je stvar odgoja. Mi smo specifični za razliku od onih ljudi koji su imućni i čija su djeca bahata, ponašaju se kako hoće. Mi smo primjer."(RBZ1).

Jedan od posebno istaknutih indikatora dobrobiti djece je i obrazovanje. Roditelji su posebno naglasili »probleme u pristupu obrazovanju i informacijama«. U kontekstu siromaštva i aspekta obrazovanja, roditelji posebno ističu steškoće podmirivanja troškova obrazovanja«: »Knjige su strašno skupe za bilo koju školu, pogotovo za fakultet. Kad pogledate, to je strašno velika investicija. Ažao mije da dijete koje se trudi ne može ići dalje." (RBZ7); »Obrazovanje. Ona je htjela ić' dalje, alije zbog novaca... sedam tisuća kuna košta večernja škola. I onda nije mogla ić' dalje, a jezici joj idu dobro. I sad je na burzi, sad čeka posao, ali nema ga. Ona je mislila da će se zaposlit' pa će ić' u večernju školu, ali ništa od toga." (RBZ4). Roditelji posebno naglašavaju problem »neusklađenosti obrazovnog sustava s tržištem rada《: »/ djeca završe školu, neko zanimanje kojeg u struci uopće nema... radnik na stroju, u poljoprivredi, neki radnici za strojeve ili nešto tamo... Ženskice na burzi ostanu paf, oni ne znaju uopće da to postoji. I sad su ta djeca prepuštena ulici.« (RBZ7). Roditelji ukazuju na veliku zakinutost njihove djece zbog »nemogućnosti korištenja računala $i$ interneta « zbog teške financijske situacije: "Sad je imala završni rad sad za napisat na kompjuteru, nije imala gdje napisat, tako da je morala ić u knjižnicu i tako par puta." (RSZ5); »Evo, našsin ide za kompjutere imora imat'kompjuter i mora imat' internet, jerne može bit' informatičar.... Ali dijete ide u tu školu!... Ne može učit', njemu profesori šalju zadaću preko kompjutera, sve informacije preko kompjutera, sve on to mora stavljati na usb-ove." (RBZ7); »Pa morali smo isključit internet, kod kuće sada nemam interneta, evo imamo kompjuter, prašina se kupi na njemu već, jer smo internet isključili, previše je to 250 kuna davat, jer ne možemo internet bez fiksne linije. Troši, ne troši, 250 kuna.« (RSZ7). Roditelji ističu i otežani pristup informacijama, odnosno »nedovoljnu informiranost o pravima«:» Pretpostavljam da su sva naša djeca zakinuta za pristup informacijama." (RBZ1); »Eto, stipendije za djecu, to je jedna informacija koju nismo znali.« (RBZ7); »Pa eto, sad za maturalac... Te agencije uvijek imaju mogućnost jedno dijete koje je siromašnije uzeti sa sobom, ali oni to ne rade. Oni tu informaciju uopće ne žele staviti na stol, a kamo li da jedno dijete putuje s njima vis-a-vis što nema." (RBZ7).

U konačnici, kada sagledavamo što je zajedničko svim roditeljima, bez obzira u kojoj zajednici žive, jest i »pozitivan odnos djece prema obrazovanju«. Roditelji pritom naglašavaju »dobra obrazovna postignuća djece«: »Evo, danas je donio ocjene. Prošao je s četiri, nema nijedan sat neopravdanog, nijednog problema ni ništa, treći razred srednje škole, od 18 predmeta. Mislim da je to stvarno dobro u ovim uvjetima..." (RBZ7) i »odgovornost prema školskim obvezama«: »Nemam s njima problema, svi uče za sebe, znači, super su.« (RSZ1).

\section{8 članci}




\section{Specifične razlike u doživljaju dobrobiti djece iz perspektive roditelja koji žive u siromašnijoj i bogatijoj \\ zajednici}

lako se roditelji neovisno iz koje zajednice dolaze u mnogome preklapaju glede indikatora dobrobiti djece, uočene su i neke specifičnosti s obzirom na zajednicu iz koje dolaze (Tablica 3).

Tablica 3. Dobrobit djeteta u kontekstu odrastanja u siromaštvu iz perspektive roditelja - specifičnosti siromašnije i bogatije zajednice

\begin{tabular}{|c|c|c|c|}
\hline \multicolumn{4}{|c|}{ Tema: Dobrobit djeteta u kontekstu odrastanja u siromaštvu } \\
\hline \multicolumn{2}{|c|}{ Roditelji iz siromašnije zajednice } & \multicolumn{2}{|c|}{ Roditelji iz bogatije zajednice } \\
\hline Kategorije & Pojmovi & Kategorije & Pojmovi \\
\hline $\begin{array}{l}\text { Problem } \\
\text { zadovoljavanja } \\
\text { osnovnih } \\
\text { životnih potreba } \\
\text { obitelji }\end{array}$ & $\begin{array}{l}\text { Poteškoće u } \\
\text { podmirivanju troškova } \\
\text { odjeće i obuće za djecu } \\
\text { Loši stambeni uvjeti }\end{array}$ & $\begin{array}{l}\text { Važnost } \\
\text { konstruktivnog } \\
\text { provođenja } \\
\text { slobodnog } \\
\text { vremena }\end{array}$ & $\begin{array}{l}\text { Volontiranje } \\
\text { Značaj bavljenja } \\
\text { izvanškolskim } \\
\text { aktivnostima } \\
\text { Roditelji financiraju } \\
\text { izvanškolske aktivnosti } \\
\text { Nedostatak financijskih } \\
\text { sredstava za slobodno } \\
\text { vrijeme djece }\end{array}$ \\
\hline $\begin{array}{l}\text { Nedostupnost } \\
\text { sadržaja i usluga } \\
\text { u zajednici za } \\
\text { djecu i mlade }\end{array}$ & $\begin{array}{l}\text { Nedostatak sadržaja } \\
\text { za konstruktivno } \\
\text { provođenje slobodnog } \\
\text { vremena } \\
\text { Nemogućnost } \\
\text { volontiranja u zajednici }\end{array}$ & $\begin{array}{l}\text { Važnost } \\
\text { obrazovanja }\end{array}$ & $\begin{array}{l}\text { Djeca iskazuju želju za } \\
\text { visokim obrazovanjem } \\
\text { Podrška roditelja u } \\
\text { nastavku obrazovanja } \\
\text { djece }\end{array}$ \\
\hline $\begin{array}{l}\text { Nepovoljni } \\
\text { obrazovni uvjeti }\end{array}$ & $\begin{array}{l}\text { Problem izbora srednje } \\
\text { škole prema prostornoj } \\
\text { dostupnosti } \\
\text { Školovanje izvan mjesta } \\
\text { stanovanja } \\
\text { Problem plaćanja } \\
\text { troškova školovanja } \\
\text { Nekonzistentnost pri } \\
\text { ostvarivanju prava djece } \\
\text { na prijevoz }\end{array}$ & & \\
\hline
\end{tabular}

Tako se kod roditelja iz siromašnije zajednice pojavljuje »problem zadovoljavanja osnovnih životnih potreba obitelji«. To se prije svega odnosi na »poteškoće 
u podmirivanju troškova odjeće i obuće za djecu: »...problemi su ovo, egzistencijalni, odjeća, obuća, tako." (RSZ6); "Al ima nešto drugo, ovako naizgled što drugi imaju, a oni to nemaju, odjeća..." (RSZ7) i »loše stambene uvjete«: »Nemamo ni vode... cijelo evo ljeto vučem kante." (RSZ7), »Ni vode nemaš gradske." (RSZ2); »Mi čekamo već 9 godina na obnovu, krov, sve curi dolje." (RSZ5).

Roditelji iz siromašnije zajednice posebno naglašavaju »nedostupnost sadržaja i usluga u zajednici za djecu i mlade«. Pritom je prisutan »nedostatak sadržaja za konstruktivno provođenje slobodnog vremena«: »... a nemamo ni neku ustanovu gdje bi oni mogli igrat nogomet, sastati se kad su neki praznici. Nemaju ništa..«(RSZ7); »Slobodno vrijeme nemaju gdje. Nemaju gdje izaći.. (RSZ5), „Onda ode malo u kafić, neće ni stalno u kući da sjedi." (RSZ2). To se također odnosi i na »nemogućnost volontiranja u zajednici«: »...volontiranje, ovdje nemamo, to vam je, to." (RSZ6); »...srednjoškolci, volontiranje bi njima bilo zabavno, on bi to s guštom radio, kad bi oni vidjeli da su oni nekom pomogli, išo bi sa zadovoljstvom.« (RSZ7).

lako problem u pristupu obrazovanju svi roditelji ističu kao važnu prepreku, postoje dodatne specifičnosti s obzirom na život u siromašnijoj zajednici. Tako roditelji iz siromašnije zajednice posebno naglašavaju problem »nepovoljnih obrazovnih uvjeta«. Pritom ističu »problem izbora srednje škole prema prostornoj dostupnosti: »Što se tiče škole, ovdje smo prinuđeni, uzet što oni nude." (RSZ2); »lmamo šumar, stolar, ekonomist i gimnazija." (RSZ7). Kako bi djeca mogla slijediti svoje obrazovne aspiracije, odlučuju se za »školovanje izvan mjesta stanovanja«: »Moja je starija kćer, ona je u... (o.a. grad izvan mjesta stanovanja) ${ }^{5}$ išla za kuhara, druga ide u... (o.a. grad izvan mjesta stanovanja) za komercijalista." (RSZ1). Školovanje izvan mjesta prebivališta dovodi do "problema plaćanja troškova školovanja«: »A sad, ne možemo mi djecu poslat možda u ... (o.a. sudionica navodi velike gradove), ne može to svako si priuštit." (RSZ2). U kontekstu nepovoljnih obrazovnih uvjeta roditelji ističu »nekonzistentnost pri ostvarivanju prava djece na prijevoz " pa tako neka djeca nemaju plaćeni prijevoz do škole: »Mi nemamo ništa." (RSZ7) (o.a.: prijevoz djece do škole) dok drugima prijevoz plaća centar za socijalnu skrb.", »lde preko socijale." (RSZ1) (o.a.: prijevoz do škole).

Roditelji iz bogatijih zajednica posebno naglašavaju »značaj konstruktivnog provođenja slobodnog vremena« pri čemu navode da njihova djeca »volontiraju«: "Moja kćer je član udruge za prvu pomoć i volontira za ove u edukaciji u prometu, drugih mlađih... Kad su bile ove pomoći za Slavoniju, ona je išla svaki dan pakirat.» (RBZ2). Naglašavaju »važnost bavljenja izvanškolskim aktivnostima«: »...ona je jako aktivna izvan škole - od zbora u crkvi, do plesne škole, 5 dana u tjednu ima treninge, ide na takmičenja, bila je treća u svijetu. Išli su u Tursku nekoliko puta po 14 dana, Graz, Austrija, Njemačka itd. To je popunjeno jako i zabavlja se. Stalno po kući pleše.« (RBZ3).

Zbog povjerljivosti nisu navedena imena mjesta i gradova koji se mogu povezati sa sudionicima.

\section{0 članci}


S obzirom na isticanje važnosti konstruktivnog provođenja slobodnog vremena, neki roditelji ističu kako »financiraju izvanškolske aktivnosti«: »Ništa nema iz kluba, nego sve iz kuće, sve mi plaćamo. Za svoje dijete, ako pokaže ikakvu mogućnost u nekom smjeru, morate je podržat'. Ako ne podržite, propali smo i ja i ona.«(RBZ2), dok drugi navode kako zbog »nedostatka financijskih sredstava djeca slobodno vrijeme" provode kod kuće: »Nemaju mobitel, nemaju izlaske, pogotovo ovaj stariji, ne može van, jer nema za sok, nema za kavu.« (RBZ7).

U bogatijoj zajednici roditelji posebno ističu važnost nastavka obrazovanja te se mogu uočiti »visoke obrazovne aspiracije«. Pritom »djeca iskazuju želju za visokim obrazovanjem «: »E sad, ova mlađa, ona je 3. godina, komercijalna, ona kaže: 'Ja ću ići na faks, ja neću biti ovako.'" (RBZ4). Prisutna je "podrška roditelja u nastavku obrazovanja djece«: »Ja bih htjela da se moja kćer školuje dalje, ali odakle da joj platim?« (RBZ4), "Zato smo mi pokušali za svojeg sina kako bi išao dalje, da dobije stipendiju..... (RBZ7).

\section{Socijalna podrška obiteljima koje žive u uvjetima siromaštva}

Socijalna podrška podrazumijeva dostupnost resursa u socijalnoj okolini koji pojedincu pružaju podršku u svakodnevnom životu te kriznim situacijama i time pridonose njegovoj dobrobiti. Najčešće dimenzije socijalne podrške su emocionalna, instrumentalna i savjetodavna podrška. Emocionalna podrška podrazumijeva moralnu podršku, razumijevanje osjećaja i promišljanja, empatiju te brigu pojedinca i okoline za drugoga. Instrumentalna ili materijalna podrška pruža osobi izravnu potporu u obliku usluga i materijalnih dobara, dok savjetodavna uključuje davanje savjeta, uputa, prijedloga ili povratnih informacija o djelovanju pojedinca (Dobrotić i Laklija, 2012.). Socijalna podrška može se sagledavati kao neformalna i formalna. Neformalnu podršku pruža najbliskija okolina, kao što su obitelj, rodbina, prijatelji i susjedi. Formalna podrška odnosi se najčešće na institucionalnu vrstu pomoći, koja je pružana od strane državnih i lokalnih ustanova, udruga civilnog društva, humanitarnih i vjerskih organizacija (Družić Ljubotina, Kletečki Radović i Ogresta, 2016.).

Kroz treće tematsko područje željelo se saznati tko djeci i roditeljima pruža pomoć i podršku, na koji način, te od koga očekuju podršku u daljnjem životu. Razlike u obliku i razini podrške obiteljima nisu uočene s obzirom na pripadnost sudionika siromašnoj ili bogatoj zajednici. Stoga će u nastavku biti prikazani skupni rezultati za sve roditelje (Tablica 4.). 
Tablica 4. Doživljaj socijalne podrške obiteljima koji žive u uvjetima siromaštva zajedničko svim roditeljima

Tema: Doživljaj socijalne podrške obiteljima koje žive u uvjetima siromaštva

Kategorija

\begin{tabular}{|c|c|}
\hline Kategorija & Pojam \\
\hline \multirow{3}{*}{$\begin{array}{l}\text { Prisutnost neformalnih i } \\
\text { formalnih izvora podrške }\end{array}$} & Obiteljska kohezija \\
\hline & Materijalna i emocionalna podrška susjeda i prijatelja \\
\hline & $\begin{array}{l}\text { Instrumentalna podrška institucija (CZSS, lokalna } \\
\text { samouprava, humanitarne organizacije) }\end{array}$ \\
\hline \multirow{4}{*}{$\begin{array}{l}\text { Socijalna isključenost } \\
\text { i nezadovoljstvo } \\
\text { socijalnom podrškom }\end{array}$} & Osjećaj stigmatiziranosti i izoliranosti od okoline \\
\hline & Nedostupnost informacija o pravima \\
\hline & $\begin{array}{l}\text { Nedovoljna senzibiliziranost stručnjaka za problem } \\
\text { siromaštva }\end{array}$ \\
\hline & $\begin{array}{l}\text { Problem zakonodavnog okvira i nesuradnje između sustava } \\
\text { Izostanak podrške obitelii i susieda }\end{array}$ \\
\hline
\end{tabular}

Kao što je vidljivo iz prethodne tablice, roditelji imaju različita iskustva vezana uz socijalnu podršku. Mnogi od njih navode "prisutnost neformalnih i formalnih izvora podrške«. Tako posebno ističu kao važan izvor neformalne podrške »obiteljsku koheziju«: "Drži me to što imam živu i zdravu djecu i njihovu potpunu ljubav $i$ utjehu. Kad mi je najteže, imam njih." (RBZ6); »Uzajamno poštovanje, podrška, dogovori i uzajamno odricanje. Kako nemam ja za neke luksuze, tako nema ni on." (RBZ7); „...mama je tu, uskoči, ali ima i nas s moje obitelji što kaže puno, većinom su svi vani, imam brata dolje u Bosni... svi smo složni što se tiče toga pomaganja, i ovako." (RSZ1); »Meni sestra puno pomaže, onda ja idem koji put, popeglam kad generalku ima. Da mi i mesa i garderobu." (RBZ4); "Ovaj mlađi sin je ove godine bio u maškare i on je sve što je zaradio donio kući. 'Mama, tebi to više treba nego meni.' Mene je to tako zaboljelo. Nije ga nitko tražio, sam je to htio. Kad je on to stavio na stol, prisjelo mi je, koliko god mi je trebalo." (RBZ7); »Da, na sinu najviše, on isto ide kod susjeda pomagat sijeno, i to i, i onda da zaradi koju kunu, pa da meni, kaže: 'Mama, nešto mi kupi za to.'" (RSZ5). Neformalna podrška odnosi se i na »materijalnu i emocionalnu podršku susjeda«: »Ja jedino ovako ako treba posudit novac za lijek kad se razboli netko, ja ili muž, za put do bolnice, to možemo od susjeda posudit..." (RSZ4) i »prijatelja«: »..onda s prijateljima, što kaže s njima mogu i, da ne kažem i psovat svima i nasmijat se, i podijelit tugu i sve što kaže.« (RSZ1); "...ili sa savjetima, bilo kako.«(RSZ6). Roditelji ističu postojanje formalne podrške, odnosno podrške djelatnika različitih institucija s kojima su u kontaktu. To se odnosi prije svega na »instrumentalnu podršku institucija«, kao što su centar za socijalnu skrb (CZSS), lokalnu zajednicu i humanitarne organizacije: »Ja sam dobila za sina, trebala sam za bolnicu u Dubravi za operaciju... otišla kod djelatnice CZSS-a, viče možemo, al moramo navesti da je to za bolničke, ovaj troškove... i dobila sam 1400

\section{2 članci}


kuna. Nešto sam platila za prijevoz... bolnicu nisam plaćala zato što sam ja s njime bila i dali su.« (RSZ3);»Prošle godine je grad plaćao 60\%, ali samo osmogodišnjoj, srednjoj ne." (RSZ3); »Kod nas za ogrjev dobiješ 950 kuna." (RSZ1); »Odjeća, obuća, odem tamo u... (o.a. humanitarna organizacija), slabo, sve slabije, bilo je bolje kad je bila ona ženskica tamo... Što se tiče higijene, dobijemo dva sapuna, dva kaladonta, i vlažne maramice jedne, mislim, vrlo malo.«(RSZ4).

Roditelji su ipak više svjedočili o svom osjećaju »socijalne isključenosti i nezadovoljstva socijalnom podrškom «. Pritom su naglašavali »osjećaj stigmatiziranosti $i$ izoliranosti od okoline «: »Kad dođete tamo, to vam je tako strašno podcjenjivanje, da to ne možete. Ona gospođa koja sjedi, prvo uzme osobnu kartu. Onda vas gleda kao da ste došli krast', a ne da je to badava .." (RBZ7); "Mi smo, mi smo stigmatizirani... odmah u startu." (RSZ6); (Bez novca propadaš, odvojiš se od društva, odvojiš se od svega." (RBZ3). Posebno su se zadržali na problemu »nedostupnosti informacija o pravima«: »Mi mnogi ne znamo za pomoć garderobe, mnogi ne znaju za pomoć gradsku, ja ne znam za ovo... Mi nemamo informacija! (RBZ2); »Neka kontroliraju, ja sam za to, ali neka mi kaže i neka prava. Ja se iznenadim čisto, i nekad i pozitivno, al više negativno. Pa daj mi taj zakon da ja vidim gospođo šta piše u tom zakonu. Pa ja ništa ne znam..." (RSZ6). Prethodna dva pojma su nerijetko povezana i s »nedovoljnom senzibiliziranosti stručnjaka za problem siromaštva«: "A tu kad dođemo i kažemo da treba uzet nešto robe za djecu il' hrane, kaže obratite se X, X nas ne doživljava, ko ljude. Mislim, oni se loše ponašaju prema nama. Kad je bilo te humanitarne donacije odjeće, obuće, hrane, to uopće nije došlo u ruke onih kojima je potrebno. Mi nemamo više snage ni otić pokucat na ta vrata, jer smo doživjeli takve neugodnosti da se sa suzama vratǐ̌." (RSZ7); "Kad dođete tamo, to vam je tako strašno podcjenjivanje, da to ne možete." (RBZ7); "...ali, besplatna je hrana, a ja sam plaćala za dijete taj mjesec hranu. I meni nastavnica, nikakva tajna nije, ona je rekla ma šta se vi mama više bunite, pa koliko ima ljudi da rade, a nemaju plaću, vi imate svaki mjesec bar sigurno. Ovdje ste mi se popeli.« (RSZ7); »...u školi su profesori rigorozni. Ako nema taj tren knjige u školi na stolu, pa vas zove u školu, dere se, špota, ne možeš im objasnit'..." (RBZ4); "Što mene jako ljuti i nedavno mi je jedna isto od socijalnih radnica naljutila kad je došla na izvid, muž je izašao vani jer bi reagirao. Ako se boriš, čistiš, nešto možda i privrediš, posadiš neko cvijeće. Kad dođe u dvorište s vrata kaže oh vama je lijepo, zašto vi primate socijalnu pomoć ili u vas je ovako u vas je onako." (RSZ7). Roditelji su često u razgovoru naglašavali »problem zakonodavnog okvira«, koji im ponekad otežava život i nije u skladu s njihovim potrebama: »...nakon javnih radova... nije teško izvadit papire to je sve na istom mjestu, al ti nemaš pravo 2 mjeseca na socijalnu pomoć, ti od zraka 2 mjeseca živiš. Izgubiš prava na knjige, izgubiš prava na drva, nemaš nikakva prava." (RSZ7) i »nesuradnje između sustava«: »Tako da se u svakom slučaju rad udruga, rad socijalnih radnika i nas mora zbližit'." (RBZ2); "Drugim riječima, Ministarstvo obrazova- 
nja i socijala ne surađuju..." (RBZ1). lako smo ranije mogli vidjeti da roditelji navode prisutnost različitih oblika neformalne podrške, činjenica je da ima i drugačijih iskustava te da kod nekih od njih izostaje podrška bliske okoline. To se odnosi na »izostanak podrške obiteljik: „Evo, moj otac danas... Ni čestitka svom unuku, ni poruka preko telefona, ni ruka, ništa, kao da to dijete ne postoji. A on u njemu gleda maltene sve najviše na svijetu jer nema s druge strane ni bake ni ništa." (RBZ7), kao $i$ »susjeda«: „Ja, na primjer, ne bi o nekim stvarima među susjedima, među ljudima tu u selu ni pričala ni komentirala, jer bi se kasnije bojala njihove reakcije kad ja odem, svi te kao sažalijevaju, ja ne tražim sažaljenje, onda kad okreneš leđa, ovo ono, što ne idu radit... ovaki su, onaki su.» (RSZ7).

U konačnici, u razgovoru s roditeljima, kao izvor snage i podrške otvorila se tema »vjere u boga«: »Ja mogu reć', najveća stvar koja mene drži, to je vjera u boga." (RBZ2); "Ono što me tješi i drži je vjera....kad se pomolim, lakše je.» (RSZ4). Vjera se pokazala kao izvor snage roditeljima u teškoj materijalnoj situaciji te bi u budućim istraživanjima bilo vrijedno istražiti ovaj aspekt suočavanja osoba koje žive u teškoj materijalnoj situaciji.

\section{Mogućnosti ublažavanja učinaka siromaštva djece iz perspektive roditelja}

Posljednje tematsko područje odnosilo se na prijedloge i preporuke roditelja koje bi doprinijele smanjivanju učinaka teške materijalne situacije na život obitelji i djece. U nastavku će biti prikazane preporuke i prijedlozi na deskriptivnoj razini.

U kontekstu ublažavanja učinaka siromaštva obitelji s djecom, roditelji ističu kako je najbitnije da im se osiguraju osnovni životni uvjeti i zapošljavanje. Tu naglašavaju da su im najpotrebniji »novac i hrana«: »Novac i hrana." (RBZ5); »Da, te dvije točke, novac i hrana, su kritične i ključne.» (RBZ6). Nadalje, roditelji navode potrebu zapošljavanja kroz »otvaranje novih radnih mjesta i omogućavanje zapošljavanja mladih«: » I ovoj djeci koja su završila škole da im omoguće radna mjesta." (RSZ1) i »roditelja: »Zaposlit nas." (RBZ2) te »zapošljavanje većeg broja mladih preko učeničkog istudentskog servisa «: »A većina bi srednjoškolaca, vjerujem da bi i kćer od RSZ2, i moj sin sad dok su na ferju išli, išla bi i ta djeca na sezonu preko studentskog, pa nek je pranje posuđa, al djeca bi zaradila taj dinar koji bi njima bio sladak, vjerujte mi.« (RSZ7).

Također su naglasili potrebu izmjene zakonodavnih odredbi za ostvarenje novčane pomoći na način da se "poveća visina iznosa socijalne pomoći«: »Umjesto da se digne ta pomoć, obaveza je da se digne, jer mi što dobivamo, to graniči s minimalcem."

\section{4 članci}


(RBZ2), »smanje uvjeti za ostvarivanje navedenog prava«: »A znate kakvi uvjeti su - nek' samo jedan uvjet ne ispunjavate od, recimo, 8 ili 6 uvjeta koji oni zadaju, nemate pravo na ništa. I onda vam sve ukidaju, nema režija, nema pomoći, nema jednokratne pomoći, nema kuhinje, nema garderobe." (RBZ2) te da postoji »mogućnost vraćanja novaca korisnicima nakon što prilože plaćene račune : »Ne moramo imati protok novca kroz džepove, ali možemo tjedne račune iz nekih dućana sakupiti i donijeti i netko može vratiti novac. Naše dijete može ići na maturalac, može dobiti 50\% nazad. Naše dijete može imati aktivnost košarke ili putovanja, donesimo račun, vrati se $70 \%$. Neću da ispašta moje dijete. A da dobijem bilo kakvu pomoć, ja bih presretan bio.« (RBZ3), što je vezano uz izmjenu regulacije načina ostvarivanja prava na jednokratnu naknadu.

Još jednom naglašavaju potrebu za većom podrškom različitih sustava s kojima se obitelji i djeca koja žive u siromaštvu susreću. Roditelji pritom ističu sustav obrazovanja za koji smatraju da bi trebao posebno svojim mjerama podržati djecu i obitelji koje žive u uvjetima siromaštva. Oni navode da je potrebno »pomoći potpore usmjeriti na obrazovanje djece«: »Besplatne knjige im trebaju osigurat.« (RSZ4); »Djeca trebaju besplatnu kuhinju..." (RSZ5), »Još jedan komentar za srednjoškolce koji bi sad trebali, ako bog da, sad ić' na fakultet. Te stipendije, a i srednjoškolske stipendije, to je onako, malo više od ništa. Tu bi se možda država trebala ponuditi da pomogne nama, obiteljima koji smo u takvoj situaciji, da barem ta djeca mogu ostvariti svoju budućnost i svoje zanimanje, i da mogu naprijed u život.« (RBZ1). Veća senzibiliziranost sustava uključuje i "potrebu za boljim odnosom djelatnika socijalne skrbi«: »l trebali bi imat' malo više razumijevanja kad dođete u teške životne situacije. Kad dođete razgovarat', da vas bar pogleda, sasluša, gleda u oči ili osmijeh, a ne bacit' papire na stol, izađe, 'Vratit ću se.', pa 'Čekajte, telefon.', a vama je u mozgu ludilo. A tih 5 minuta, da čovjeka gleda u oči, više bi značilo nego ne znam što." (RBZ7).

Na kraju, specifično za siromašnije zajednice, roditelji navode kako je potrebno »organiziranje aktivnosti za djecu i mlade«: »Ja bi na primjer to, volila bi nešto za djecu, dobro Zje mali pa ga odvedem nekad u park kad smo u trgovini, pa onda bude s njim u parku muž ili ja. Al volila bi za X i Y bilo šta da imaju, nek je i vožnja biciklom, da imaju nešto, bar na jedan dan u tjednu gdje će oni..« (RSZ7), organizirati »radionice i igraonice za djecu i mlade«: »Mala smo mjesta da bi se oformile, oformile te radionice, kojekakvi servisi." (RSZ6); "Ja bi na primjer bila presretna kad bi bila bilo kakva igraonica, bar na jedan dan da djeca odu da se djeca ispuše, da dožive svoju slobodu. Da oni se provedu onako kako bi oni htjeli.« (RSZ7). Roditelji naglašavaju važnost mogućnosti »volontiranja za mlade«: »...volontiranje isto to nije loša stvar ako to nije profit.« (RSZ6); »Da, nek je besplatan poso, nek dijete ide da malo radi. Neće mislit kod kuće na gluposti, neće mu ni padat u glavu.«(RSZ7). 


\section{RASPRAVA}

Roditelji djece koja žive u uvjetima siromaštva navode nekoliko ključnih područja problema s kojima se njihove obitelji suočavaju, a koje vide kao posljedicu ekonomske krize. To se odnosi na osnovne životne uvjete potrebne za bazično preživljavanje djece i obitelji. Pritom navode da oskudijevaju u hrani, odjeći i obući, podmirivanju troškova stanovanja, ali naglašavaju i neke elemente pada životnog standarda, kao što je, primjerice, nemogućnost odlaska na ljetovanje. lako je sustav socijalne skrbi usmjeren prije svega na osiguravanje osnovnih životnih potreba obiteljima i pojedincima koji žive u uvjetima siromaštva, nemogućnost zadovoljavanja osnovnih životnih potreba i dalje ostaje jednim od ključnih problema s kojima se ovi korisnici suočavaju. To su pokazala i recentna sveobuhvatna istraživanja provedena u Hrvatskoj s korisnicima sustava socijalne skrbi (Šućur i sur., 2015.; Družić Ljubotina, Kletečki Radović i Ogresta, 2016.). Roditelji ističu brojne probleme vezane uz nezaposlenost i tržište rada, koji su, očekivano, istaknuti kao ključni problemi koji su povezani s dubinskim siromaštvom. Osim već poznatih problema nezaposlenosti siromašnih osoba zbog nekonkurentnosti na tržištu rada i zdravstvenih teškoća kojima su siromašne osobe češće izložene, istaknut je i problem zapošljavanja mladih. Ovaj fenomen postao je osobito prisutan u vrijeme ekonomske krize i nerijetko se veže uz termin »novog « siromaštva (Šućur, 2014.; World Bank, 2010.). Naime, takvim oblikom siromaštva posebno su pogođene mlade osobe kao teško zapošljiva kategorija u Republici Hrvatskoj. Roditelji navode kako njihova djeca, upravo zbog problema nezaposlenosti, vide izlaz u odlasku u inozemstvo. Ističu probleme povremenih poslova, koji im donose materijalnu nesigurnost i neizvjesnost te se onda radije odlučuju ostati u sustavu socijalne skrbi, jer im to donosi kakvu-takvu financijsku predvidivost i sigurnost. Ukazuju na teškoće podmirenja specifičnih potreba svoje djece, koje nisu vezane samo uz egzistencijalne uvjete, već i uz obrazovanje i neke osobne potrebe. Tu ističu problem podmirenja, za djecu iznimno važnih, troškova vezanih za obrazovanje, ali i za troškove, primjerice, interneta i mobitela. Internet i mobitel su ključna komunikacijska sredstva današnjeg vremena, osobito u mladih ljudi. Nedostupnost ovih komunikacijskih sredstava djecu dovodi do svojevrsne degradacije unutar njihove socijalne mreže, osobito u području obrazovanja i vršnjačkih skupina, što u konačnici može dovesti do socijalne isključenosti (Bradshaw, 2011.). Problem dostupnosti modernih tehnologija u siromašnim obiteljima s djecom, u ovom je istraživanju bio svojevrsni lajtmotiv, jer je bio apostrofiran kroz gotovo sve tematske cjeline. Roditelji su ukazivali na problem nerazumijevanja nastavnika zbog nedostupnosti računala i interneta, ali i djelatnika u sustavu socijalne skrbi koji su ovu potrebu djece i mladih smatrali luksuzom te nisu odobravali novčanu pomoć za podmirenje takvih troškova. Poseb-

\section{6 članci}


no značajno je bilo od roditelja doznati na koje načine siromašna obitelj s djecom opstaje i koje strategije preživljavanja razvija. Pokazalo se da, osim što se roditelji bave povremenim »sitnim « poslovima, i djeca doprinose svojim radom obiteljskom budžetu. Roditelji se odriču brojnih svojih potreba kako bi djeci mogli priuštiti što nesmetanije zadovoljavanje njihovih potreba, pri čemu štede i na nekim osnovnim životnim potrebama i posuđuju novac od bliske okoline. Kao što je poznato, ekonomski stres ostavlja negativne posljedice na obiteljske odnose, što se pokazalo i u ovom istraživanju. Loša materijalna situacija, prema iskazima roditelja, dovela je do dubokog nezadovoljstva i osjećaja frustracije kod njihove djece, koja se nalaze u vrlo osjetljivoj dobi podložnoj utjecaju vršnjaka. Roditelji se suočavaju s nerazumijevanjem, ogorčenošću i osjećajem stigmatiziranosti od strane svoje djece. Takvi osjećaji javljaju se kao posljedica nemogućnosti uklapanja njihove djece u okvire koji su postavljeni unutar današnjih zahtjeva obrazovnog sustava, ali i materijalnih vrijednosti koje žive današnji »prosječni« adolescenti.

S obzirom na indikatore dobrobiti djece, koji su bili u središtu zanimanja ovog istraživanja, roditelji ističu nekoliko ključnih aspekata. Pritom posebno naglašavaju emocionalnu ranjivost svoje djece zbog posljedica života u siromaštvu i nemogućnosti zadovoljenja njihovih potreba. Kao što je ranije navedeno, roditelji uočavaju postojanje dubokog nezadovoljstva kod djece, ali i prisutnost srama zbog siromaštva. lako djeca imaju različita iskustva u odnosu s vršnjacima, roditelji su više naglašavali stigmatiziranost i socijalnu izolaciju djece od strane vršnjaka. Aspekti dobrobiti vezani uz područje osjećaja i odnosa s vršnjacima pokazali su se vrlo indikativnima u kontekstu siromaštva mladih (Bradshaw, 2011.) te je na njih potrebno obratiti posebnu pažnju stručnjaka koji su u dodiru s ovom djecom, jer mogu ostaviti dugoročne negativne posljedice na emocionalni život mladih osoba, koje se nalaze u vrlo delikatnom formativnom životnom razdoblju. Osjećaji narušenog dostojanstva i srama zbog života u siromaštvu česti su problemi koje naglašavaju osobe s iskustvom siromaštva (Šućur i sur., 2015.; Družić Ljubotina, Kletečki Radović i Ogresta, 2016.). lako suočeni s brojnim problemima koji se nepovoljno odražavaju na obiteljsku dinamiku, roditelji ponovno naglašavaju pozitivna iskustva vezana uz aspekt dobrobiti koji se odnosi na obitelj. Pritom ističu važne aspekte obiteljske kohezije, kao što su podržavajući odnosi i povjerenje. Navode i posebno razumijevanje, koje neki roditelji uočavaju kod svoje djece, vezano za tešku materijalnu situaciju obitelji. Iz ovih i ranijih rezultata možemo zaključiti da isticanje vrijednosti obitelji predstavlja značajan zaštitni faktor kontekstu života djece u siromaštvu. Obitelj se pokazala ključnim mjestom podrške, pri čemu odnosi u obitelji ostavljaju značajan trag kod djece. Poznato je da dobri obiteljski odnosi mogu predstavljati važan zaštitni čimbenik u djetinjstvu, a različita istraživanja pokazuju da je lošiji materijalni status povezan s većim nezadovoljstvom obiteljskim odnosima (Conger i Elder, 
1994.; Conger, Conger i Martin, 2010.). Narušenim obiteljskim odnosima pogoduje stres izazvan materijalnom oskudicom te se često odražava na partnerske odnose, koji mogu postati konfliktni. Ekonomski stres, uz narušene partnerske odnose, može se odraziti na probleme mentalnog zdravlja (primjerice depresiju), ali i na kvalitetu roditeljstva (Mistry i sur., 2010.).

U konačnici, roditelji, neovisno jesu li iz siromašne ili bogate zajednice, ističu indikator dobrobiti djece koji se odnosi na aspekt obrazovanja. Općenito, u ovom je istraživanju obrazovanje djece istaknuto kao posebno važan čimbenik. Roditelji ističu pozitivne i negativne aspekte vezane uz područje obrazovanja pri čemu su jedinstveni da ono ima egzistencijalnu važnost, jer u konačnici utječe na zapošljavanje i izlazak iz kruga siromaštva. Oni ističu i negativne aspekte, od nemogućnosti podmirivanja troškova za obrazovanje djece do nesenzibiliziranosti nastavnika za problem siromaštva. Istraživanja provedena u Hrvatskoj jasno ukazuju da djeca iz ekonomski prikraćenih obitelji nemaju jednak pristup obrazovanju te su im životne šanse i mogućnosti izbora ograničene same po sebi (UNDP, 2009.).

Roditelji iz siromašne zajednice ukazuju na značajan problem (ne)dostupnosti usluga, uzrokovanih životom u nerazvijenoj zajednici. To se prije svega odnosi na češće isticanje problema zadovoljavanja osnovnih životnih potreba, koje je teže zadovoljiti u siromašnijim zajednicama. Poznato je da je dostupnost takvih usluga prisutnija u bogatijim zajednicama, osobito ako se radi o većem gradu. Problem s kojim se posebno suočavaju obitelji iz siromašnijih zajednica vezan je i za nedostupnost aktivnosti i usluga za mlade, koje mogu doprinijeti konstruktivnom provođenju slobodnog vremena i doprinosu zajednici u kojoj žive. Slobodno vrijeme i doprinos zajednici, također su indikatori dobrobiti djece i mladih, a roditelji iz siromašne zajednice naglašavaju nepostojanje pretpostavki za realizaciju ovih aspekata kod djece, zbog nepostojanja resursa u siromašnoj zajednici (Šućur i sur., 2015.).

Aspekt socijalne podrške je tema koja se sama po sebi nameće kad govorimo o osobama koje su u riziku od siromaštva. Siromaštvo kao rizična okolnost za rast i razvoj te kao čimbenik rizika za socijalno isključivanje može dodatno opteretiti život djeteta i fazu promjena koje se događaju tijekom odrastanja (Kletečki Radović, 2011.). Tijekom djetinjstva podrška djeci i njihovim obiteljima iznimno je važna zbog suočavanja s nizom zahtjevnih tjelesnih, emocionalnih i socijalnih promjena koje odrastanje donosi. Socijalna podrška podrazumijeva dostupnost resursa u socijalnoj okolini koji pojedincu pružaju podršku u svakodnevnom životu te kriznim situacijama, i time pridonose njegovoj dobrobiti (Dobrotić i Laklija, 2012.). Utvrđeno je da pozitivan sustav socijalne podrške pridonosi otpornosti, dobrom mentalnom zdravlju te ima učinak »zaštitne membrane« $u$ odnosu na stres (Maluccio, Pine i Tracy, 2002.; Rutter i sur., 1998., prema Pinkerton i Dolan, 2007.). Djeca s jakom socijalnom podrškom bolje su prilagođena društvu u kojem žive od djece

\section{8 članci}


koja dobivaju manje društvene podrške (Dubow i sur., 1991.; Ladd, 1994.; Levitt, Guacci-Franco i Levitt, 1993., prema Vasta, Haith i Miller, 1998.). U kontekstu teme koja se odnosi na doživljaj socijalne podrške, roditelji ponovno ističu značaj obitelji te obiteljsku koheziju kao važan izvor podrške. To je u skladu s ranije komentiranim nalazom u kontekstu indikatora dobrobiti djece istraživanjem UNICEF-a o siromaštvu predškolske djece u Hrvatskoj (Šućur i sur., 2015.), gdje se obitelj pokazala također najvažnijim mjestom podrške. Nadalje, s obzirom na formalnu podršku, pokazalo se da siromašnim obiteljima nedostaje usmjerena i sustavna podrška od strane institucija i drugih dionika. lako navode prisutnost neke osnovne instrumentalne podrške, koja je sastavni dio egzistiranja tih ustanova, ostaje ogroman prostor nezadovoljene potrebe za formalnom podrškom organizacija, stručnjaka, ali i zakonodavnog okvira, koji se dovode u doticaj s problemom siromaštva. Razlog nezadovoljstva roditelja formalnom podrškom moguće je tražiti i u nedovoljnoj senzibiliziranosti donositelja politika za problem siromaštva. Nedovoljna osviještenost donositelja politika za problem siromaštva je tema o kojoj se sve više raspravlja i naglašava u krugovima stručnjaka koji se bave problemom siromaštva. Neosviještenost o višedimenzionalnosti fenomena siromaštva (Davis i Wainwright, 2005.; Krumer-Nevo, Weiss-Gal i Monnickendam, 2009.) i njegova socijalnog, zdravstvenog i psihološkog aspekta dovodi do djelovanja koje je usmjereno uglavnom na dodjelu bazične materijalne pomoći, a izostaju mjere, pomoć i podrška osnaživanju obitelji i djece, kako bi izašli iz kruga siromaštva. Problem predstavlja i okolnost koja se odnosi se na činjenicu da u Hrvatskoj ne postoji jasan teorijski model djelovanja u radu s ranjivim obiteljima s djecom (Ajduković i Radočaj, 2008.). Stoga je nužno unutar sustava koji dolaze u direktan doticaj sa siromašnim obiteljima, educirati stručnjake, o specifičnostima pristupanja u radu s djecom i obiteljima koje žive u uvjetima siromaštva (Družić Ljubotina i Kletečki Radović, 2011.). Siromašna djeca najčešće ostaju nevidljiva djelatnicima sustava ako njihovi roditelji nisu obuhvaćeni nekim drugim mjerama (primjerice, obiteljsko-pravne zaštite). Stoga je jedan od prioritetnih ciljeva Nacionalne strategije za prava djece u Republici Hrvatskoj 2014.-2020. godine upravo "senzibilizirati i educirati stručnjake o temama u vezi s dječjim siromaštvom te osigurati kompetentne stručnjake $u$ različitim sustavima za pristupanje i provođenje intervencija s djecom koja žive u uvjetima siromaštva« (MSPM, 2014.: 67). Ovaj problem, sudeći prema rezultatima istraživanja, ali i praksi u sustavu socijalne skrbi, još uvijek nije dovoljno prepoznat.

U konačnici, roditelji su imali priliku poručiti koji su njihovi prijedlozi za unapređenje položaja siromašnih obitelji s djecom, a na temelju vlastitog iskustva života u siromaštvu. Tu prije svega ponovno naglašavaju nužnost većeg ulaganja u zadovoljavanje osnovnih životnih potreba i otvaranja mogućnosti zapošljavanja. Još jednom ističu važnost i potrebu za većim razumijevanjem sustava i stručnjaka koji 
su u doticaju sa siromašnom djecom i obiteljima. Nalazi s preporukama prikazani su na deskriptivnoj razini, jer se pokazalo da ova tema nije bila pogodna za bogatu raspravu. Ta činjenica može se razmatrati i u kontekstu ograničenja ovog istraživanja. Naime, pokazalo se da su roditelji, kada je trebalo na neki način generalizirati svoje iskustvo kroz preporuke i prijedloge za unapređenje položaja siromašnih obitelji s djecom, vrlo sažeto odgovarali, bez puno deskriptivnih pojašnjenja i bogatstva rasprave. Jedan od mogućih razloga je što roditeljima nije bilo jednostavno generalizirati iskustvo siromaštva na razinu preporuka i verbalizirati in kako bi se došlo do razine apstrakcije.

Osim prethodno navedenog ograničenja s obzirom na poteškoću sudionika da svoja iskustva generaliziraju u obliku preporuka, u nastavku ćemo se osvrnuti na još neka metodološka ograničenja ovog istraživanja pod vidom kojih je potrebno dobivene rezultate razumijevati i interpretirati. $U$ ovom istraživanju provedene su dvije fokusne grupe s roditeljima u zajednicama različito kapacitiranim resursima. $S$ obzirom na razlikovanje iskustava roditelja koji žive u bogatijoj i siromašnijoj zajednici, broj provedenih fokusnih grupa nije omogućio postizanje teorijske zasićenosti. Stoga dobivene rezultate treba razmatrati unutar geografskog konteksta u kojem su provedene, uvažavajući specifičnosti zajednica koje su doprinijele nalazima koji su prikazani u istraživanju. Pod vidom stjecanja dubljeg uvida u perspektivu podizanja djece u uvjetima siromaštva i učinaka na dobrobit djece, a s obzirom na okolinske čimbenike, valjalo bi proširiti uzorak sudionika, odnosno povećati broj fokusnih grupa u svakoj zajednici. Uvjeti za postizanje teorijske zasićenosti podrazumijevaju provođenje minimalno po tri fokusne grupe u svakoj zajednici kako bi se eventualno mogle iscrpiti sve potencijalne teme i dobiti cjelovitiji uvid u doživljaj roditelja u nošenju sa siromaštvom i učincima na dobrobit njihove djece obzirom na karakteristike sredine u kojoj obitelji žive. $U$ tom smislu, provedeno istraživanje i dobiveni nalazi predstavljaju početne uvide o specifičnostima siromaštva i podizanja djece u bogatijim i siromašnijim zajednicama.

No, bez obzira na ovo ograničenje, nalazi ovog dijela projekta dosljedno su ukazali na jedan aspekt koji do sada nije bio u fokusu istraživanja siromaštva, a to su razlike u životu i mogućnostima siromašnih obitelji s djecom u bogatijim i siromašnijim zajednicama. S obzirom da su te razlike o životu i mogućnostima siromašnih obitelji vrlo jasno prisutne i u dijelu istraživanja u kojem su sudjelovala djeca (Kletečki Radović, Vejmelka i Družić Ljubotina, 2017.), projekt je u cjelini ukazao da je u budućim istraživanjima nužno voditi računa, kako u konceptualizaciji samog istraživanja, tako i u strategijama uzorkovanja, o ovim razlikama. Stoga ukazivanje na ove razlike predstavlja mogućnost značajnih metodoloških unapređenja u budućim istraživanjima.

\section{0 članci}




\section{ZAKLJUČAK}

Ovo istraživanje pokazalo je da se obitelji koje žive u uvjetima siromaštva suočavaju s brojnim teškoćama, preprekama i izazovima u podizanju djece. Roditelji ukazuju na različite negativne posljedice koje je ekonomska kriza ostavila u njihovim obiteljima, od nemogućnosti zadovoljavanja osnovnih životnih potreba ili otežanog pristupa obrazovanju djece pa do problema narušenih obiteljskih odnosa i osjećaja socijalne isključenosti. Rezultati su otvorili ponovno neke nove-stare uvide o tome s kojim se problemima suočavaju djeca i obitelji koje žive u uvjetima siromaštva. Neki od tih problema prepoznati su i u Nacionalnoj strategiji za prava djece u Republici Hrvatskoj 2014.-2020. godine (MSPM, 2014.), u dijelu koji se odnosi na problem siromaštva djece. Tako se, primjerice, u ovom značajnom dokumentu koji je donijela Vlada Republike Hrvatske, i koji je na snazi već tri godine, navodi kako je nužno kroz sustav socijalne skrbi razvijati programe pomoći i podrške koji nisu isključivo orijentirani na dodjelu novčane potpore, već na individualno i socijalno osnaživanje kroz mrežu prostorno, vremenski i ekonomski dostupnih socijalnih usluga usmjerenih razvoju resursa za uključivanje i prosperitet djeteta i obitelji u zajednici. U njemu se ukazuje i na problem dostupnosti socijalnih usluga ranjivim skupinama djece i djece koja žive u uvjetima siromaštva. U skladu s aspektima dobrobiti djece, u ovom dokumentu se apostrofira činjenica kako djeca koja žive u uvjetima siromaštva imaju veći rizik od ranog napuštanja školovanja ili stjecanja nižeg stupnja stručne kvalifikacije. Kako bi se prevenirali takvi rizici, predlažu se programi usmjereni na unapređenje vještina učenja djece, popravljanje školskog uspjeha, prevenciju napuštanja školovanja u situacijama kada su djeca neuspješna u školi, mentorstvo ili vođenje kroz sustav visokog obrazovanja. Navode se mjere poput: donošenja nacionalnog plana borbe protiv dječjeg siromaštva; razvoja programa podrške uključivanja roditelja djece iz siromašnih obitelji u tržište rada; osiguravanja modela osnaživanja obitelji za suočavanje s rizicima i posljedicama siromaštva; osiguravanja pristupa i ostvarivanja usluga iz različitih sustava socijalnih politika u zajednici u cilju razvoja optimalnih uvjeta za razvoj potencijala djeteta; prevencije posljedica siromaštva djece te unapređenje položaja djece koja žive u uvjetima siromaštva kroz uključivanje djece u različite nestigmatizirajuće psihosocijalne programe pomoći i podrške; razvijanje mehanizama i metoda sudjelovanja djece koja žive u uvjetima siromaštva u sustavu odgoja i obrazovanja, zdravstva, socijalne skrbi te na razini nacionalne i lokalne i područne (regionalne) samouprave s ciljem socijalnog uključivanja i povećanja vidljivosti ove ranjive skupine djece, itd. Iz navedenih prioritetnih mjera, na polovici vremenskog razdoblja u kojem bi one trebale biti realizirane, možemo zaključiti da su dobro ciljane. One su velikim dijelom u skladu s rezultatima našeg istraživanja, no činjenica je da su za sada vidljive 
samo na deklaratornoj razini, pri čemu još uvijek nije zaživjela operacionalizacija ovih mjera niti u jednom njihovom dijelu.

Kako u konačnici reagirati na gore navedeno stanje u kojem niti jedna od navedenih mjera ove Nacionalne strategije o pravima djece još nije zaživjela? Čija je to odgovornost? Iz dokumenta jasno proizlazi da ključnu odgovornost ima država, odnosno ministarstvo nadležno za poslove socijalne skrbi i socijalnu politiku. $\mathrm{Na}$ koji način djelovati i potaknuti državu da primijeni mjere koje je sama propisala, a tiču se najranjivijih skupina djece? Možda odgovor leži upravo u jednoj od ranije spomenutih mjera koju je resorno ministarstvo u ovom dokumentu navelo, a to je: »Senzibilizirati i educirati stručnjake o temama u vezi s dječjim siromaštvom te osigurati kompetentne stručnjake $u$ različitim sustavima za pristupanje i provođenje intervencija s djecom koja žive u uvjetima siromaštva« (MSPM, 2014.: 67). U kontekstu odgovora na pitanje čija su odgovornost djeca koja žive u uvjetima siromaštva, vratimo se na cilj cijelog projekta »Indikatori dobrobiti i siromaštva djece u Hrvatskoj u doba krize: Kako prekinuti začarani krug siromaštva djece?«. Naime, cilj je bio bolje razumijevanje učinaka siromaštva na dobrobit i kvalitetu života djece i jačanje društvene odgovornosti za olakšavanje ovog prioritetnog socijalnog, te za pojedino dijete vrlo značajnog razvojnog problema. Jačanje društvene odgovornosti uključuje, uz državu koja ima najveću moć utjecati na promjene unutar svojih sustava, i akademsku zajednicu. Uloga i odgovornost akademske zajednice, uz otvaranje relevantnih spoznaja o različitim socijalnim problemima, jest i aktivno zagovaranje ranjivih skupina, kao što su i siromašna djeca. Ovim se istraživanjem koje su osmislili i proveli djelatnici akademske zajednice, željelo osim proširenja spoznaja, utjecati na javne politike koje se tiču siromaštva djece. Nadamo se da će upravo kreatori politika kojima je u fokusu dječje siromaštvo prihvatiti paradigmu da se materijalna sredstva koja država izdvaja za prevenciju siromaštva i podizanje razine skrbi za siromašnu djecu ne bi smjela kratkovidno sagledavati iz diskursa troškova. Izdvajanja za djecu koja žive u uvjetima siromaštva potrebno je sagledavati iz perspektive dugoročnog ulaganja, što bi omogućilo unapređenje položaja i dobrobiti djece te povećalo šanse za izlazak iz kruga siromaštva.

\section{2 članci}




\section{LITERATURA}

1. Abela, A. \& Berlioz, G. (2007). Support for parenting of children at risk of social exclusion. In: M. Daly (ed.), Parenting in contemporary Europe: A positive approach. Strasbourg: Council of Europe Publishing.

2. Ajduković, M. \& Radočaj, T. (2008). Pravo djeteta na život u obitelji. Zagreb: Ured UNICEF-a za Hrvatsku.

3. Bradshaw, J. (2011). The well-being od children in the UK. The Policy Press.

4. Bradshaw, J., Hoelscher, P. \& Richardson, D. (2007). Comparing child well-being in OECD countries: Concepts and methods. Innocenti Working Paper No. 2006-03. Florence: UNICEF Innocenti Research Centre.

5. Bronfenbrenner, U. (1979). The ecology of human development. Experiments by nature and design. Cambridge: Harvard University Press.

6. Conger, R. D. \& Elder, G. H. (1994). Families in troubled times. New York: Aldine de Gruyter.

7. Conger, R. D., Conger, K. J. \& Martin, M. J. (2010). Socioeconomic status, family processes, and individual development. Journal of Marriage \& Family, 72 (3), 685-704.

8. Davis, A. \& Wainwright, S. (2005). Combating poverty and social exclusion: Implications for social work education. Social Work Education, 24 (3), 259-273.

9. Dobrotić, I. \& Laklija, M. (2012). Obrasci društvenosti i percepcija izvora neformalne socijalne podrške u Hrvatskoj, Društvena istraživanja, 21 (1), 39-58.

10. Družić Ljubotina, O. \& Kletečki Radović, M. (2011). Siromaštvo i socijalni rad: Koliko je siromaštvo doista »tema« socijalnog rada? Ljetopis socijalnog rada, 18 (1), 5-29.

11. Družić Ljubotina, O. \& Kletečki Radović, M. (2016). Siromaštvo i djeca. U: Hrabar, D. (ur.), Prava djece - multidisciplinarni pristup. Zagreb: Pravni fakultet Sveučilišta u Zagrebu.

12. Družić Ljubotina, O., Kletečki Radović, M. \& Ogresta, J. (2016). Slika podrške beskućnicima u Hrvatskoj. Zagreb: Gradski ured za socijalnu zaštitu i osobe s invaliditetom.

13. Državni zavod za statistiku (2015). Pokazatelji siromaštva u 2014. godini. Priopćenje 14.1.1. Preuzeto s: https://www.dzs.hr/Hrv_Eng/publication/2015/14-01-01_01_2015.htm (10.7.2017.).

14. Državni zavod za statistiku (2016). Geografska raspodjela rizika od siromaštva i socijalne isključenosti za mala područja u Republici Hrvatskoj. Zagreb: DZS. Preuzeto s: http://bit.ly/2el0dJJ (10.7.2017.).

15. Geinger, F., Roets, G. \& Vandenbroeck, M. (2017). Families with young children in times of economic downturn: Implications for social work practice. International Journal of Social Welfare, In press. 
16. Gershoff, E. T., Raver, C. C., Aber, J. L. \& Lennon, M. C. (2007). Income is not enough: Incorporating material hardship into models of income asociations with parenting and child development, Child Development, 78 (1), 70-95.

17. Guo, G. \& Harris, K. M. (2000). The mechanisms mediating the effects of poverty on children's intellectual development. Demography, 37, 431-447.

18. Kletečki Radović, M. (2011). Siromaštvo ineki aspekti psihosocijalnog razvoja djece. Doktorska disertacija. Zagreb: Pravni fakultet.

19. Kletečki Radović, M., Vejmelka, L. \& Družić Ljubotina, O. (2017). Učinak siromaštva na dobrobit i kvalitetu života obitelji iz perspektive djece. Ljetopis socijalnog rada, 24, (2), 243-276.

20. Konvencija o pravima djeteta. Preuzeto s: http://www.unicef.hr/upload/ file/300/150215/FILENAME/Konvencija_20o_20pravima_20djeteta.pdf (13.7.2017.).

21. Krumer-Nevo, M., Weiss-Gal, I. \& Monnickendam, M. (2009). Poverty-aware social work practice: A conceputal framework for social work education. Journal of Social Work Education, 45 (2), 225-243.

22. Lacey, A. \& Luff, D. (2009). Qualitative research analysis. East Midlands/Yorkshire \& The Humber: The NIHRDS.

23. Linver, M. R., Brooks-Gunn, J. \& Kohen, D. E. (2002). Family processes as pathways from income to young children's development. Developmental Psychology, 38 (5), 719-734.

24. Minujin, A., Delamonica, E., Gonzalez, E. D. \& Davidziuk, A. (2005). Children living in poverty: A review of child poverty definitions, measurements and policies. Desk Review paper for UNICEF's Conference on Children \& Poverty: Global Contex, Local Solutions. New York: Unicef.

25. Mistry, R. S., Vandewater, E. A., Houston, A. C. \& McLoyd, V. C. (2002). Economic well-being and children's social adjustment: The role of family process in an ethnically diverse low-income sample. Child Development, 73, 935-951.

26. Mistry, R. S., Benner, A. D., Biesanz, J. C., Clarck, S. L. \& Howes, C. (2010). Family and social risk, and parental investments during the early childhood years as predictors of low-income children's school readiness outcomes. Early Childhood Research Quarterly, 25 (4), 432-449.

27. MSPM (2014). Nacionalna strategija za prava djece u Republici Hrvatskoj 2014.-2020. godine. Zagreb: Ministarstvo socijalne politike i mladih.

28. Pinkerton, J. \& Dolan, P. (2007). Family support, social capital, resilience and adolescent coping. Child and Family Social Work, 12 (3), 219-228.

29. Raboteg-Šarić, Z. (2006). Siromaštvo i dobrobit djece. U: UNDP: Neumreženi: Lica socijalne isključenosti u Hrvatskoj. Izvješće o društvenom razvoju, Hrvatska.

\section{4 članci}


30. Redmond, G. (2008). Child poverty and child rights: Edging towards a definition. Journal of Children and Poverty. 14 (1), 63-82.

31. Ritchie, J. \& Spencer, L. (1994). Qualitative data analysis for applied policy research. In: Bryman, A. \& Burgess, R. (eds.), Analyzing qualitative data. London: Routledge, 173-194.

32. Srivastava, A. \& Thomson, S. B. (2009). Framework analysis: A qualitative methodology for applied policy research. Journal of Administration \& Governance, $4(2), 72-79$.

33. Šućur, Z. (2014). Stari i novi siromasi u hrvatskom društvu: Empirijski uvid. Bogoslovska smotra, 84 (3), 577-610.

34. Šućur, Z., Kletečki Radović, M., Družić Ljubotina, O. \& Babić, Z. (2015). Siromaštvo i dobrobit djece predškolske dobi u Republici Hrvatskoj. Zagreb: Ured UNICEF-a za Hrvatsku.

35. UNDP (2009). Mladi između obrazovanja i zapošljavanja: Isplati li se školovati? Zagreb: UNDP Hrvatska.

36. UNICEF (2014). Children of the recession. The impact of the economic crisis on child well-being in rich countries. Innocenti Report Card 12. Florence: UNICEF Office of Research.

37. Vasta, R., Haith, M. H. \& Miller, S. A. (1998). Dječja psihologija. Jastrebarsko: Naklada Slap.

38. World Bank (2010). Croatia: Social impact of the crisis and the policy response - An assessment. Washington: World Bank.

39. Yeung, W. J., Linver, M. R. \& Brooks-Gunn, J. (2002). How money matters for young children's development: Parental investment and family processes. Child Development, 73,1861-1879.

40. Zajedničke europske smjernice za prijelaz $s$ institucionalne skrbi na usluge podrške u zajednici (2012). Preuzeto s: http://www.deinstitutionalisationguide. eu (14.7.2017.).

41. Zakon o socijalnoj skrbi $(2013,2014,2015,2016,2017)$. Narodne novine, $157 / 2013$. , 152/2014., 99/2015., 52/2016., 16/2017. 
Olja Družić Ljubotina

University of Zagreb

Faculty of Law of the

Department of Social Work

Teodor Sabolić

Social Welfare Center Varaždin

Marijana Kletečki Radović

University of Zagreb

Faculty of Law of the

Department of Social Work

\section{FAMILIES WITH CHILDREN LIVING IN POVERTY: PARENTS PERSPECTIVE}

\section{ABSTRACT}

This paper presents the results of a of qualitative research that was conducted as part of a project entitled »/ndicators of child well-being and poverty in Croatia at the time of crisis: How to break the vicious circle of child poverty? « by a research team from the Social Work Study Centre at the Faculty of Law of the University of Zagreb, with the financial support of the ADRIS Foundation. The aim of the research was to gain insight into the perspective and opinion of the parents of children/youth concerning the effects of the economic crisis on the well-being and quality of life of children and their families and, specifically, the possibility of mitigating the effects of poverty on children. Two focus groups were organised that consisted of a total of 14 parents of secondary-school students from families that exercise the right to guaranteed minimum remuneration. The results show that the economic crisis had a deleterious effect on various aspects of the quality of life of families and on the well-being of children. It is shown that the life of material scarcity has led to the inability to satisfy one's basic living needs, problems in settling the costs of education, dilapidated family relations, development of various strategies for facing poverty, etc. From the aspect of children's well-being, the dimension of dissatisfaction and emotional vulnerability of poor children, problems in peer relations, inaccessibility of information, etc., was particularly prominent. Parents view employment as the key protective factor against poverty and emphasize the importance of support and a higher level of sensibility on the part of experts who come into contact with poor families and children. This study highlights differences in current life and opportunities available to poor families with children in better off and poorer communities that should be taking in consideration when planing future reserch.

Key words: poverty, children, parents, well-being, resources of local communities.

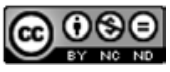

Međunarodna licenca / International License:

Creative Commons Attribution-NonCommercial-NoDerivatives 4.0.

\section{6 članci}

